\title{
ČLÁNKY
}

\section{Závazkové nástroje ochrany smluvního věřitele korporace začleněné do podnikatelského seskupení ${ }^{1}$}

\section{The Contract Law Approach to Creditor Protection in Corporate Group}

\author{
Zdeněk Houdek*
}

\begin{abstract}
Abstrakt
Pres stále rostouci význam a ekonomickou sílu podnikatelských seskupení absentuje jednotná definice tohoto jevu, jehož podoby zahrnuji spektrum od vysoce centralizovaných po silnè diversifikované skupiny společností. S obledem na majetkovou samostatnost mater'ské společnosti a omezené ručeni (odpovédnost) spolećnikè zuistává kličcovou otázkou, do jaké míry mĩže být mateřská společnost odpovědná za porušení závazku mezi dceřnou společnosti a věritelem v prípadech, kdy je dceriná společnost ovlivnèna jednáním materské společnosti. Následujici článek analyzuje závazkové nástroje ochrany vérìtele korporace začlenèné do podnikatelského seskupení. Je dovozováno, že nárok véritele dceriné společnosti proti společnosti mateřské můž být založen na predpokladech a podminkách aplikace institutu culpa in contrahendo spolu s prvky smlouvy s ochranným úcinkem ve prospèch tretího.
\end{abstract}

\section{Klíčová slova}

Podnikatelské seskupeni; skupiny společnosti; culpa in contrabendo; smlouva sochranným účinkem ve prospèch tretího; piercing of corporate veil.

\begin{abstract}
The significance of corporate groups continues to increase, as well as their economic power. There is no uniform definition of corporate groups and the concept covers the spectrum from bighly centralized to largely diversified groups. With limited shareholder liability for parent companies as the general norm, the leading question in the following is to what extent a parent company can be beld liable for performance breaches of its subsidiary, who is actually contracting with the client, even though she is bound to follow instructions from the parent company. The following treatise analyses the preconditions of creditor protection in corporate group, which is based on the application of contractual instruments of creditor protection. It is concluded that subsidiary creditors can have a standing in a lawsuit against a parent corporation based on preconditions for
\end{abstract}

* Mgr. Zdeněk Houdek, asistent, Katedra obchodního práva, Právnická fakulta, Masarykova univerzita, Brno/ Instructor, Department of Commercial Law, Faculty of Law, Masaryk University, Brno, Czech Republic / E-mail: Zdenek.Houdek@law.muni.cz

1 Za cenné podněty a prripomínky děkuji kolegům z katedry J. Kotáskovi, J. Šilhánovi a R. Rubanovi. 
the imposition of culpa in contrahendo by third parties and elements derived from the third party protection contracts.

\section{Keywords}

Corporate Group; Culpa in Contrahendo; Third Party Protection Contracts; Piercing of Corporate Veil.

\section{Úvodem}

„I weigh my words, when I say that in my judgment the limited liability corporation is the greatest single discovery of modern times, (...) Even steam and electricity are far less important than the limited liability corporation."

Nicholas Murray Butler, 1911

Byla-li v počátcích svého vzniku kapitálová obchodní korporace nahlížena jako izolovaně, samostatně stojící hospodářská jednotka, je současná realita využití této formy podnikání zcela odlišná. Převažující podobu podnikání přebírá taková forma organizace, kdy je činnost strukturována do skupin (byt’ právně samostatných), presesto hospodářsky či vlastnicky úzce propojených obchodních korporací. Majetková samostatnost² právnické osoby, jakožto její definiční znak, ${ }^{3}$ spolu s možností jedné právnické osoby nabývat účast na jiné, a to dokonce i jako jediný společník, umožnily vznik fenoménu

2 Patrně nejvýstižnější označení této vlastnosti přináší H. Hansmann a R. Kraakman, pokud hovoří o Defensive Asset Partitioning, které lze při jisté míře zjednodušení ztotožnit s omezeným ručením (omezenou odpovědnostnî) společníků. HANSMANN, H. a R. KRAAKMAN. The Essential Role of Organizational Law. Yale Law Jurnal [online]. 2000, roč. 110, č. 3, s. 411-413 [cit. 14. 6. 2019]. Dostupné z: https://www.yalelawjournal.org/article/the-essential-role-of-organizational-law

3 V. Knapp uvedené vyjadřuje tak, že „sdruženi osob fyzických, popr. i právnických jsou de lege lata právnickou osobou tehdy, jestliže jejich majetek jako korporace je oddèlen od majetku členu korporace, tžn. jestliže majetek sdružený cleny korporace, nezávisle na zpuisobu a rozsabu jejich osobníbo dlužnictvi za závazky korporace, neni vlastnictvím téch, kedo jej v korporaci sdružili, ale vlastnictvím korporace samé jako právního subjektu od nich odlišného. "KNAPP, V. O právnických osobách. In: Právník, 1995, roč. 124, č. 10-11, s. 992; obdobně B. Havel uvádí „Právní osobnost s sebou prinnási také majetkovou samostatnost právnické osoby, protože jeji majetek neni majetkem zrizovatele, členü nebo společnikiu, ale jen majetkem samotné právnické osoby. Na této skutećnosti nic nemèni ani trv. ekonomické vlastnictví, které zpravidla může náležet vériteliom nebo spolecníkiom". HAVEL, B. Občanský qákoník - velký komentár.

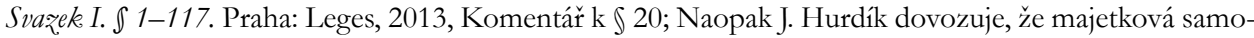
statnost není pojmovým znakem, který lze připsat jakékoliv právnické osobě. Vychází přitom z obsahu tohoto pojmu, kterým chápe oddělní majetku a majetkovou odpovědnost tak, že tyto vlastnosti jsou výrazem obecnějších rysů, a to speciální subjektivity a způsobilosti k právním úkonům, resp. způsobilosti deliktní. Tedy jinými slovy, existence majetkové samostatnosti je odrazem právní osobnosti právnické osoby. HURDÍK, J. Právnické osoby (Obecná právni charakteristika). Brno: Masarykova univerzita, 2000, s. 148; K pojmu subjektivity blíže RUBAN, R. K právní subjektivitě, povaze a jednání právnických osob. In: Casopis pro právní védu a praxi, Brno: Masarykova univerzita, 2013, roč. 21, č. 3, s. 388-397. Dostupné z: https://journals.muni.cz/cpvp/article/view/5703; Dále viz např. BAINBRIDGE, S. M. a M. T. HENDERSON. Limited liability: a legal and economic analysis. Cheltenam, UK: Edward Elgar Publishing, 2016, s. 5 a násl.; WITTING, Ch. A. Liability of Corporate Groups and Networks. Cambridge: Cambridge University Press, 2018, s. 3 a násl. 
podnikatelských seskupení (skupin společnostî), které efektivně využívají synergických výhod takovéto formy organizace. Nejde o jev, který by byl v době vzniku moderní korporace ${ }^{4}$ jakkoliv zamýšlený či předpokládaný, ${ }^{5}$ přesto si jeho úspěch dokázal podmanit podobu podnikatelského světa 20. století. Ačkoliv jsou popsány i další důvody ${ }^{6}$ vzniku této formy organizace podnikání, raison d'être existence skupin spočívá právě ve využití majetkové samostatnosti právnické osoby, jež umožňuje izolovat podnikatelská rizika od částí majetku či je alespoň efektivně diversifikovat. ${ }^{7}$ Iritující otázkou tohoto „,rozložení sil““ zůstává ochrana věřitele některé z formálně samostatných korporací před nekompenzovaným přenosem rizika. ${ }^{8}$ Obzvláště uvážíme-li, že v prrípadě koncentrace kapitálové účasti, jakou skupiny společností představují, se již plně neuplatní důvody, které jsou obecně s majetkovou samostatností obchodní korporace spojovány. ${ }^{9}$ Vstupní princip ochrany věřitele je přesto jednoznačný: věřitelé korporace nemají zásadně žádný nárok vi̊či majetku členů korporace; či jinak - nároky věřitelů nesahají (přímo) mimo majetkovou sféru zavázané korporace.

Právní řády nabízí variaci přístupů a množství mechanismů ochrany věřitele před možnými negativními dopady tohoto jevu. Domácí předpis obsahuje v nejobecnější rovině pravidlo \ 71 ZOK, které je postaveno na deliktní povaze uplatněného „škodlivého“ vlivu a zakládá (v některých př́padech) ručení vlivné osoby věřiteli. ${ }^{10}$ Otázka jeho věcné a osobní působnosti však není zcela uspokojivě vyřešena, a to zejména $\mathrm{v}$ př́padech,

4 Rozumím zde to, co bývá označeno jako „Berle-Means Corporation“, tedy veřejně obchodovaná akciová společnost s roztř́šš̌nou vlastnickou strukturou, ve které se plně projevuje princip diverzity, tedy oddělení správy společnosti od jejího reziduálního vlastnictví. BERLE, A. a G. MEANS. The modern corporation and private property. 4. vyd. New Brunswick: Transaction Publishers, 2002, s. 355.

5 BLUMBERG, P. I. The Multinational Challenge to Corporation Law: The Search for a New Corporate Personality. Oxford: Oxford University Press, 1993, s. 54 a násl.

$6 \mathrm{~K}$ důvodům vzniku skupin viz ČERNÁ, S. Koncernové právo v Nèmecku, Evropské unii a České republice. Praha: C. H. Beck, 1999, s. 1 a násl.; či DOLEŽIL, T. Koncerny v komunitárním právu: analýza a náméty pro rekodifikaci. Praha: Auditorium, 2008, s. 31 a násl.

7 PELIKÁN, R. Skupiny společností v obchodním právu. In: XIX. Karlovarské právnické dny. Praha: Leges, 2011, s. 396.

8 Např. GERNER-BEUERLE, C. a M. A. SCHILling. Comparative Company Law. Oxford: Oxford University Press, 2019, s. 46-47.

9 Jako základní ekonomické výhody odůvodňující nutnost defensivního oddělení majetku korporace bývají uváděny: a) výhody specializace plynoucí z oddělení správy a řízení od residuálního vlastnictví korporace, b) snižování informačních a monitorovacích nákladů společníků, c) možnost diversifikace investic a rizika $\mathrm{z}$ nich vyplývajících, d) převoditelnost podílu a z ní plynoucí efektivita kapitálového trhu. Napr. EASTERBROOK, F. H. a D. R. FISCHEL. The economic structure of corporate law. 4. vyd. Cambridge: Harvard University Press, 1998, s. 59; HALPERN, P., M. TREBILCOCK a S. TURNBULL. An Economic Analysis of Limited Liability in Corporation Law. The University of Toronto Law Journal [online]. 1980, roč. 30, č. 2. s. 1127 a násl. [cit. 14. 6. 2019]. Dostupné z: https://www.jstor.org/ stable/825483

10 HAVEL, B. Zákon o obchodních korporacích. Komentár. 2. vyd. Praha: C. H. Beck, 2017, s. 199-208. 
je-li důvod uplatnění vlivu konstruován na jiné skutečnosti než kapitálové účasti vlivné osoby. $^{11}$

Můžeme předpokládat, že ochranné schéma věřitele upravené v \ 71 ZOK není úplné. $\mathrm{Na}$ to ostatně reaguje i důvodová zpráva, když uvádí, že ,zákon sice nezavádí pravidla piercing of corporate veil, nicméně navazuje na ně tím, že pro případné poškození společnosti a její následnou nemožnost plnit zavádí ručení vlivné osoby za splnění dluhů ovlivněné osoby. Tím se kombinuje ochrana jak samotné společnosti, tak jejích věřitelů. Samotná pravidla prolomení slupky odpovědnostního subjektu pak nejsou věcí tohoto zákona, ale výkladu deliktních pravidel zákoníku občanského. “12

Zájem domácí právní nauky o doktrínu piercing of corporate veil (Durchgriffshaftung) jistě není okrajový. ${ }^{13}$ Konkrétní doporučení se však fakticky omezují na konstatování potřebnosti takové doktríny, popř́padě - po německém vzoru - zakládají tuto doktrínu na pravidlech náhrady škody způsobené úmyslným jednáním v rozporu s dobrými mravy. Předkládaná stat' je dalším prŕíspěvkem do této diskuse, nebot' se snaží hledat nástroje ochrany smluvního věřitele, který může být dotčen výkonem kontroly, jež plyne ze začlenění jeho dlužníka do širší podnikatelské skupiny. Mám za to, že v těchto př́padech je nutno hledat subtilnější kritéria dopadu výkonu vlivu, která mohou mít význam na prolomení relativity vztahu mezi ovlivněnou korporací a dlužníkem, než jen př́mý zásah do existence (bonity) ovlivněné korporace, tak jak by předpokládalo odpovědnostní schéma založené po německém vzoru (Existenzvernichtungshaftung), ale ostatně i $\int 71 \mathrm{ZOK}$.

Na konkrétních př́kladech se pokusím demonstrovat situace, kdy lze nalézt dobrý důvod pro založení př́mé odpovědnosti „vlivné“ osoby vůči věřiteli „ovlivněné“ korporace. Dále bude představen takový výklad zvláštních deliktních pravidel občanského zákoníku, který rozšiřuje ochranu smluvního věřitele pro tyto případy. Na tomto místě je třeba zdůraznit, že odpovědnostní schéma navrhované v příspěvku dopadá na dobrovolné věřitele

$11 \mathrm{~K}$ tomu např. HAVEL, B. Věritel coby vlivná osoba (aneb vliv není totéž co být pod vlivem). In: XXIV. Karlovarské právnické dny. Praha: Leges, 2016, 540 s.; HAVEL, B. O kogentnosti, vypořádání újmy a ručení vlivné osoby ve světle nového soukromého práva. In: Obchodněprávní revue, 2013, č. 1, s. 13 a násl.; ČERNÁ, S. Ještě k ručení vlivné a ovládající osoby za porušení povinnosti odvracet hrozící úpadek. In: Obchodnéprávní revue, 2013, č. 6, s. 169 a násl.; ČERNÁ, S. O koncernu, koncernovém řízení a vyrovnání újmy. In: Obchodněprávní revue, 2014, č. 2, s. 33 a násl.; ČERNÁ, S. Ovlivnění jako klíčový pojem českého koncernového práva. In: Rekodifikace a praxe, 2014, č. 1, s. 14 a násl.

12 Důvodová zpráva k návrhu zákona č. 90/2012 Sb., o obchodních společnostech a družstvech. In: CODEXIS [právní informační systém]. Atlas Consulting [cit. 1. 2. 2019].

13 Za všechny sprov. např. KOSTOHRYZ. M. Piercing the corporate veil: prekeonáni právní samostatnosti kapitálových společností v srovnávacím pohledu. Praha: Univerzita Karlova v Praze, 2013, 130 s.; LOKAJÍČEK, J. Prolomeni majetkové samostatnosti kapitálových společností. Praha: C. H. Beck, 2016, 161 s.; ČERNÁ, S. Lze prolomit hranice majetkové samostatnosti obchodní společnosti? In: Nové jevy v právu na počátku 21. století. IV. Promény soukromého práva. Praha: Karolinum, 2009, 424 s.; PATĚK, D. K možnosti prolomení majetkové samostatnosti české společnosti s ručením omezeným. In: Nové jevy v právu na počátku 21. století. IV. Promèny soukromébo práva. Praha: Karolinum, 2009, 424 s. 
korporace. Otázka ochrany věřitelů nedobrovolných (typicky deliktních) je ponechána stranou a není předmětem zkoumání v tomto př́íspěvku.

Stranou je ponechána také zákonná úprava podnikatelských seskupení dle $\int 71$ a násl. ZOK, byt' v samém závěru se $\mathrm{k}$ ní ještě jednou vracíme. Úvahy zde představené jsou obecnější; tomu odpovídá i zvolená terminologie, kdy je pojem mateřské a dceřiné společnosti pojímán obecnějším způsobem, než je zákonná definice $\int 74$ odst. 2 ZOK. Prvotní úvahy proto směřují k přiblížení „neostrých“ hranic pojmu skupiny společností.

\section{Struktura a vymezení pojmu podnikatelského seskupení}

Chceme-li nacházet limity ochrany věřitele podnikatelského seskupení, jistý problém přináši již samotná charakteristika tohoto jevu. Hovoříme-li o skupinách společností, není zcela zřejmé, jaký ohraničený fenomén je tímto spojením pojímán.

Domácí právní nauka tradičně definuje podnikatelské seskupení pomocí dvou definičních znaků, a to právní samostatnosti a ekonomické jednoty, jako takový projev ekonomické koncentrace v oblasti práva, pro nějž je charakteristické spojování jednotlivých právně samostatných subjektů do ekonomického celku sledujícího vlastní podnikatelské zájmy při zachování právní samostatnosti jednotlivých osob. ${ }^{14}$ Ve své vrcholné podobě tvoří podnikatelská seskupení ekonomický celek, který operuje na trhu podle jednotné strategie určované subjektem stojícím na špičce seskupení. Přidává-li se znak jednotného řízení, lze v souvislosti s podnikatelským seskupením (alespoň v reáliích domácího, resp. německého př́stupu) hovořit o koncernu. ${ }^{15,16,17}$

O existenci skupiny proto můžeme hovořit $v$ případě, kdy je dána a) skupina právně samostatných osob, které spojuje b) jednotný hospodářský a finanční zájem a mezi nimiž existuje c) výkon kontroly.

Jakkoliv problémy nepůsobí naplnění první z těchto tří složek, zbylé dvě proměnné se uplatňují aproximativně a patrně nelze přesně definovat, za jakých podmínek jsou či nejsou naplněny. Tyto potíže nejsou nijak překvapivé, uvážíme-li, že zde hledáme právní definici pojmu, jehož koncept vyvěrá více z ekonomické oblasti než z oblasti právní. ${ }^{18}$

14 ČERNÁ, S. Koncernové právo v Nèmecku, Evropské unii a Céské republice. Praha: C. H. Beck, 1999, s. 4.

15 ČERNÁ, S. Faktický koncern, ovládaci smlouva a smlouva o prevodu ziskeu. 2. dopl. vyd. Praha: Linde, 2004,244 s.

16 Problémy přesné definice tohoto jevu jsou patrné i v práci Hejdově, který uvádí řadu možných definic koncernu. Z nich patrně nejprriléhavější je definice Passowa, který definuje koncern jakožto „skupinu občanskoprávnè samostatných podnikè, jež tvoř určitou hospodárskou jednotku a podléhají jednotnému vedeni". HEJDA, J. Hospodárská funkece akciové společnosti. Praha: Česká národohospodářská společnost, 1930, s. 113.

17 Či definici Hexnera, totiž že „koncernami sa rozumejú rozličná spojenia, keteré za společnébo blavného vedenia a za jednostrannej, alebo vzajomej kapitálovej súvislosti účastníko umožnuju úspory na režiji a lepišie využitie závodov. " HEXNER, E. Základy kartelovébo práva. Praha: Tlačovými podnikmi ústredného svazu ČSL, 1929, s. 26.

18 MEVORACH, I. The role of enterprise principles in shaping management duties at times of crisis. European Business Organization Law Review [online]. 2013, vol. 14, no. 4, s. 475 [cit. 14. 6. 2019]. Dostupné z: https://doi.org/10.1017/S1566752912001279 
Tomu odpovídá široká škála variant, jakých podob může struktura skupiny nabývat. Již na úrovni ekonomické integrace lze na jedné straně uvažovat o konglomerátech či jiných vysoce diversifikovaných skupinách, kdy propojené korporace operují v různých oblastech podnikatelské činnosti a kdy je míra společného zájmu skupiny limitována v otázkách finančních či administrativních a kde není integrovaná výroba či distribuce. ${ }^{19}$ $\mathrm{Na}$ straně druhé lze identifikovat skupiny úzce ekonomicky sjednocené, které de facto vystupují jako jediná entita se smíšenými aktivy a pasivy napříč skupinou (,asset-integrated groups $\left.s^{6 \sigma}\right) \cdot{ }^{20} \mathrm{~V}$ prrípadě konglomerátů jde o situaci rámcově jinou než v př́ípadě plně integrovaného podnikatelského seskupení.

Mezi těmito póly leží široké pole možností vzájemné kooperace, kdy pravidelně jednotlivé články skupiny vykonávají samostatnou podnikatelskou činnost, avšak skupina jako celek společně tvoří jedinou podnikatelskou entitu - podnik; popř́ípadě jsou jednotlivé společnosti vzájemně propojeny tak, že v rámci skupiny jsou koordinované některé z důležitých politik provozu (personální politika, účetní či daňové politiky, marketing, právní poradenství apd.).

Obdobně v úrovni kontroly může skupina nabývat různých podob od vertikální hierarchické struktury s jednotnou mateřskou společností, která vykonává řízení prostřednictvím několika úrovní dceřiných společností, až po horizontální struktury ${ }^{21}$, kde jednotlivé společnosti operují na stejné úrovni a kontrola je realizována prostřednictvím např. křrižových mandátů či na bázi pravidelných setkávání představitelů managementu jednotlivých korporací. Míra kontroly reflektuje míru hospodářské integrace, která může vyplynout jak z koordinace klíčových strategií, tak z úzké centrální kontroly a zapojení mateřské společnosti do každodenní činnosti dceřiných společností. ${ }^{22}$ Přitom právní povaha struktury skupiny nemusí nutně předurčovat, jak skupina jako celek realizuje svoje ekonomické zájmy.

19 I v tomto př́padě však mohou být zapojeny do struktury zvláštní jednotky, které slouží k optimalizaci některých funkcí skupiny (typicky odstínění rizika či daňová optimalizace), jako nap̌r. special purpose entities (SPE), joint ventures offshore trusts, income trusts, apd. $\mathrm{K}$ významu těchto pojmů bíže viz: UNCITRAL Legislative Guide on Insolvency Law. Part three: Treatment of enterprise groups in insolvency. United Nations Commission on International Trade Law [online]. York: United Nations publications, 2012, s. 7 [cit. 14. 6. 2019]. Dostupné z: https://www.uncitral.org/pdf/english/texts/insolven/LegGuide-Insol-Part3-ebook-E.pdf

20 MEVORACH, I. The role of enterprise principles in shaping management duties at times of crisis. European Business Organization Law Review [online]. 2013, roč. 14, č. 4, s. 471-496 [cit. 14. 6. 2019]. Dostupné z: https://doi.org/10.1017/S1566752912001279

21 Učebnicový prríklad takovéto „cross-holding“ struktury lze ilustrovat na př́kladu tři společnost, kdy každá drží $26 \%$ podíl v jiné a současně jsou propojeny personálně na manažerské úrovni. Tento a dalši př́klady uvádí: WITTING, Ch. A. Liability of Corporate Groups and Networks. Cambridge: Cambridge University Press, 2018, s. 4 a násl.

22 MEVORACH, I. The role of enterprise principles in shaping management duties at times of crisis. European Business Organization Law Review [online]. 2013, roč. 14, č. 4, s. 475 [cit. 14. 6. 2019]. Dostupné z: https://doi.org/10.1017/S1566752912001279 
Otázka skupin společností se však neomezuje pouze na vztah osob, které jsou propojeny kapitálovou účastí. V posledních letech získávají na významu jiné formy organizace, ve kterých formálně nezávislé podnikatelské subjekty vykonávají koordinovanou činnost pod společným řízením, kdy je vertikální integrace založena na smluvní bázi. Typicky bývají uváděny franchisingové smlouvy, licenční smlouvy, just-in-time smlouvy, ${ }^{23}$ charakteristické pro automobilový průmysl, či rozsáhle subdodavatelské řetězce ve stavebnictví. Dalším př́ikladem jsou vazby ve farmaceutickém průmyslu, kdy velké farmaceutické společnosti financují výzkum externě, nikoliv na základě kapitálové účasti, nýbrž na základě finanční podpory menších nezávislých výzkumných projektů. ${ }^{24}$

V mnoha případech mohou tyto smluvní vztahy zakládat podstatu ,společné kontroly“, která není nepodobna kontrole, jež vychází z kapitálového vlastnictví v konzervativně vnímané skupině. Jakkoliv forma je jiná, mohou i smluvní vztahy zakládat stejnou kvalitu, která umožňuje ovlivnit management a řízení, či určit základní politiky řízené společnosti. Ačkoliv v těchto formách podnikání nedochází k plné internalizaci trhu, nachází se mnohé tyto struktury na hraně mezi trhem a organizací. ${ }^{25}$

Najít tuto hranici není snadné. Obzvlášt' vývoj posledních dvou desetiletí nás přesvědčuje, že evoluce forem, ve kterých operují zejména velké a nadnárodní korporace, zdaleka nekončí na hierarchické úrovni řídící osoby a osob jí podřízených. Především v oblastech činností dotčených vysokou mírou globalizace a rozvoje technologií dochází k přemost’ování „klasické“ korporátní struktury ve prospěch ekonomického propojení aktivit na úrovni nezávislých společností; a to opět v nejrůznějších podobách: od strategických aliancí, joint ventures, ${ }^{26}$ až po sít'ové struktury (corporate networks). ${ }^{27}$

Aktuální trendy ukazují, že stejně palčivou otázkou, jako je přenos odpovědnosti v rámci skupiny korporací, je i otázka přičítání odpovědnosti v dodavatelsko-odběratelských vztazích, ve kterých je př́tomný silný prvek kontroly. ${ }^{28}$

23 BLUMBERG, P. I. The law of corporate groups: jurisdiction, practice, and procedure. Frederick, MD: Aspen Publishers, Wolters Kluwer Law \& Business, 2007, part. I, s. 6-11.

24 Zevrubně tento jev rozebírá WITTING, Ch. A. Liability of Corporate Groups and Networks. Cambridge: Cambridge University Press, 2018, s. 40 a násl.

25 Blíže k tomuto jevu viz COLLINS, H. In: Networks as Connected Contracts. Portland: Hart Publishing, 2011, s. 4 a násl.

26 Ve své podstatě jde o typ strategické aliance, která vytváří semihierarchickou strukturu korporátních vztahů.

$27 \mathrm{~K}$ významu tohoto pojmu a $\mathrm{k}$ př́kladům struktury blíže viz WITTING, Ch. A. Liability of Corporate Groups and Networks. Cambridge: Cambridge University Press, 2018, s. 39 a násl.

28 ROTT, P. a V. ULFBECK. Supply Chain Liability of Multinational Corporations? European Review of Private Law [online]. 2015, roč. 23, č. 3, s. 420; TERWIND, C. Supply Chain Liability: Pushing the Boundaries of the Common Law? In: Journal of European Tort Law [online]. 2018, roč. 8, č. 3, s. 261-296; ULFBECK, V. Supply Chain Liability for Workers' Injuries - Lessons to be Learned from Products Liability? In: Journal of European Tort Law [online]. 2018, roč. 9, č. 3, s. 269-288. 
Z uvedeného je patrné, že o skupinách společností lze jen těžko uvažovat jako o uzavřeném homogenním jevu. Široká diverzita právních i funkčních struktur, které skupiny společností mohou nabývat, představuje regulatorní výzvu, nebot' řešení, která mohou být vhodná pro jeden typ skupiny, nemusí řešit prrípady jiné. Klasická schémata regulace práva obchodních společností - založená na přiznání právní osobnosti a majetkové samostatnosti - nemusí být proto vhodným nástrojem, který dokáže detekovat a řešit zvláštní dopady existence skupin do sféry zúčastněných osob, zejména věřitelů. ${ }^{29}$

$\mathrm{V}$ dalších úvahách o podmínkách přenosu odpovědnosti je uvedené třeba mít na paměti. Je nutné zkoumat nejen to, jak nekompenzovanému přenosu externalit na věřitele brání korporátní právo jako takové, nýbrž i jaká řešení nabízí instituty závazkového a deliktního práva. Nabízí se otázka, zda právě posledně jmenované nenabízí vhodnější nástroje prolomení relativity závazkového právního vztahu a zda právě tyto instituty ve své obecnosti nedokáží lépe postihnout širokou škálu variant, kterých skupina může nabývat.

\section{Modelové situace}

Hlavním tématem tohoto příspěvku je zkoumání možných nástrojů ochrany věřitele v případech, kdy jednání osoby požívající kontrolu nad společností může zasáhnout do sféry smluvního věřitele společnosti. Jakkoliv se nabízí i další způsoby posuzování přenosu odpovědnosti uvnitř skupiny, zejména s ohledy na zájmy nedobrovolných věřitelů, ${ }^{30}$ váží se další úvahy k ochraně smluvního věritele korporace, a to v př́ípadech, je-li (již existující) závazek ke korporaci dotčen intervencí ze strany osoby, která na této korporaci vykonává kontrolu. Logicky se proto nabízí posuzovat, zda v těchto případech může být př́padná odpovědnost třetí intervenující osoby založena na pravidlech, která jsou adresována $\mathrm{k}$ řešení tohoto problému; tedy institutech spojených se smluvní odpovědností.

29 Landers pro zvýšenou expozici $\mathrm{k}$ riziku věritelů korporace začleněné do skupiny uvádí tři důvody. (i) Dostupnost finančních zdrojů $\mathrm{v}$ rámci skupiny snižuje praktický význam počáteční dostatečné kapitalizace společnosti. (ii) Nebezpečí smíšení majetku je větší mezi propojenými korporacemi, než v prostém vtahu korporace - společník. (iii) Protože je podnikatelská životaschopnost korporace provázána se skupinou, je v těchto prípadech větší šance, že jednotlivá společnost nebude schopna vykonávat nezávisle výdělečnou činnost. LANDERS, J. M. A Unified Approach to Parent, Subsidiary, and Affiliate Questions in Bankruptcy. The University of Chicago Law Review [online]. 1975, roč. 42, č. 4, s. 589-652 [cit. 14. 6. 2019] Dostupné z: http://www.jstor.org/stable/1599136

$30 \mathrm{~K}$ významu a způsobu kategorizace dobrovolných a nedobrovolných věritelů korporace bliže např.: GERNER-BEUERLE, C. a M. A. SCHILLING. Comparative Company Law. Oxford: Oxford University Press, 2019, s. 45; EASTERBROOK, F. H. a D. R. FISCHEL. Limited Liability and the Corporation. University of Chicago Law Review [online]. 1985, roč. 52, s. 104-107 [cit. 14. 6. 2019]. Dostupné z: http://chicagounbound.uchicago.edu/journal_articles; či BLUMBERG, P. I. The law of corporate groups: jurisdiction, practice, and procedure. Frederick, MD: Aspen Publishers, Wolters Kluwer Law \& Business, 2007, s. 78; Z domácí literatury nap̌r.: LOKAJÍČEK, J. Prolomeni majetkové samostatnosti kapitálových společností. Praha: C. H. Beck, 2016, s. 62; KOSTOHRYZ. M. Piercing the corporate veil: prekenáni prámi samostatnosti kapitálových společností v srovnávacím pobledu. Praha: Univerzita Karlova v Praze, 2013, s. 21 a násl.; PELIKÁN, R. Právni subjektivita. Praha: Wolters Kluwer, 2012, s. 112. 
Dříve než přistoupíme k analýze možných nástrojů ochrany smluvního věřitele, je vhodné načrtnout modelové situace, na kterých můžeme ilustrovat dále rozebírané schéma.

\subsection{První př́klad: „Fiat“}

První prŕklad je založen na rozhodnutí Vrchního zemského soudu v Stuttgartu. ${ }^{31}$ Skutkový základ sporu spočívá v charakteristice distribuční sítě automobilů společnosti Fiat (distribuční středisko Fiat). Ta byla konstruovaná jako dvouúrovňová, kdy v prvním stupni (tzv. dealer A) byla uzavřena distribuční smlouva přímo s automobilkou, na kterou byl v druhém stupni (tzv. dealer B) navázán vztah mezi dealery. Jakkoliv šlo mezi dealery obou stupňů o samostatnou smlouvu a Fiat nebyl ve smluvním vztahu k úrovni dealer B, mohla automobilka na základě smlouvy s dealerem A výrazně ovlivnit závazek mezi dealery, nebot' tato smlouva obsahovala ujednání, na jejichž základě byl dealer A zavázán přijímat doporučení ohledně vnitřní organizace a instrukce automobilky a zajistit, aby smlouva s dealerem B mohla být ukončena za určitých podmínek; smlouva mezi dealery byla také podmíněna souhlasem automobilky. Na základě pokynu ze strany automobilky vypověděl dealer A (který dle zjištění soudu neměl sám zájem tuto smlouvy vypovědět) smlouvu s dealerem B, a to v trríměsíční výpovědní lhůtě. Žalobce, dealer B, uplatnil nárok na náhradu škody, jak vůči své smluvní protistraně (dealer $\mathrm{A}$ ), tak proti automobilce Fiat. Ten byl soudem přiznán, nebot' soud dospěl k závěru, že v daném prípadě byla tříměsíční lhůta nepríměřeně krátká, a na základě doplňujícího výkladu smlouvy dovodil, že k zániku závazku došlo až po 12 měsících od výpovědi. Klíčové pro naše úvahy však je, že soud povinnost k náhradě škody nedovodil pouze vưči smluvní straně žalobce, ale též vưči automobilce Fiat.

Mezi tou a žalobcem žádný smluvní vztah nebyl. Soud ve své úvaze vyšel z existence zvláštního vztahu důvěry, který mezi stranami byl založen existencí trvalého obchodního vztahu mezi distribučním střediskem Fiat a žalobcem. Jakkoliv byl dealer B ve smluvním vztahu pouze k prvnímu žalovanému (dealerovi A), přihlédl soud ke skutečnosti, že činnost dealera B je komponentem prodejního systému, který je vytvořen, organizován a kontrolován distribučním střediskem Fiat. Postavení dealera B bylo závislé na opatřeních či rozhodnutích Fiatu, jestli ne více, tak prrinejmenším stejně jako na postupu jeho smluvní protistrany. Soud zde také naznačil jistou míru analogie s korporátním právem v úvahách o kontrolním postavení distribučního střediska Fiat, které způsobuje závislosti (začleněnî) žalobce $\mathrm{v}$ distribučním systému. Nicméně důvod uložení povinnosti $\mathrm{k}$ náhradě škody shledal soud v porušení smluvní povinnosti, která zavazovala distribuční středisko Fiat jednat s respektem k principu poctivosti a brát náležitý žretel na oprávněné zájmy i v úrovni distributora $B$.

31 Rozhodnutí Oberlandesgericht (OLG) Stuttgart ze dne 15. 9. 1989, 2 U 63/88. (NJW-RR 1990, 491). 


\subsection{Druhý př́iklad: „Volkswagen“}

Druhý ilustrativní př́klad představuje relativně nedávné rozhodnutí Vrchního zemského soudu ve Stuttgartu. ${ }^{32} \mathrm{~V}$ tomto př́padě se žalobce neúspěšně domáhal určení platnosti výpovědi leasingové smlouvy a náhrady za poskytnuté leasingové splátky. Důvodem pro ukončení leasingové smlouvy ze strany žalobce měla být ztráta důvěry vůči výrobci automobilu Porsche (resp. společnosti VW) poté, co na veřejnost pronikl skandál s manipulací $\mathrm{CO}_{2} \mathrm{u}$ automobilů této skupiny. Vrchní zemský soud připustil, že v prípadě dlouhodobého závazku, který je charakterizován požadavkem osobní důvěry, může být výjimečně shledán důvod pro ukončení smlouvy v jednání jedné ze stran, která tento požadavek důvěry naruší. ${ }^{33}$ Nicméně nárok v tomto př́padě přiznán nebyl, nebot' žalobce žádné takové jednání nedokázal prokázat. Pro rozhodnutí ve věci však bylo rozhodující především to, že žaloba směřvala proti leasingovému pronajímateli, který zde vystupoval jako nezávislá smluvní strana, a žalobce neprokázal žádné porušení smlouvy žalovaným. Pouhá skutečnost, že k nesrovnalostem ohledně $\mathrm{CO}_{2}$ došlo v jiné skupině společností, neodůvodňuje předpoklad, že žalobce legitimně ztratil důvěru vůči žalovanému.

Pro rozhodnutí tedy bylo určující, že vztah mezi žalobcem a leasingovým pronajímatelem byl zcela nezávislý na skupině VW. Pro další úvahy se však nabízí otázka, zda a jestli ano tak jak, by se tyto úvahy změnily, pokud by výpověd’ smlouvy směřovala vưči společnosti, která je součástí skupiny, kdy důvody pro narušení vztahu důvěry zakládá jednání mateřské společnosti.

Popsané př́klady je třeba chápat jako určité ilustrativní situace, které vychází z německé rozhodovací praxe, ${ }^{34}$ na nichž lze ukázat limity ochrany kontraktuálního věritele. Pokud bychom hledali ,ideální“ modelový př́iklad, můžeme takový nalézt v díle G. Teubnera. ${ }^{35}$

32 Rozhodnutí Oberlandesgericht Stuttgart ze dne 25. 4. 2017, 6 U 146/16 (LSK 2017, 108210. MDR 2017, 816).

33 K tomu např. rozhodnutí Bundesgerichtshof (BGH) ze dne 2. 9. 1999, VII ZT 225/98.

34 Podobnou skutkovou situaci však můžeme nalézt i v domácí rozhodovací praxi, v rozsudku Nejvyššího soudu ze dne 24. 4. 2019, sp. zn. 32 Cdo 2214/2017. Dovolatelka v této věci žádala přezkum otázky „zda korporace, keterá je 100\% vlastníkem podílu v jiné korporaci, odpovidá za deliketní jednáni této ovládané osoby, přpadně za jakých podminek, resp. zda je možné uplatnit výklad pojmu podnik a jeho společnou a nerozdílnou odpovédnost za protiprávni jednání v oblasti práva hospodárské soutěěe také na nyni posuzovaný prípad. "Dovolací soud uvedl, že závěry rozsudku Akzo Nobel ve vztazích soukromého práva nelze užít, ani mutatis mutandis. Blíže se však povahou vzájemného vztahu mezi mateřskou a dceřinou společností nezabýval a kasační důvody shledal v posouzení jiné právní otázky.

35 Př́klad je následující: Představme si společnost působící v sektoru finančních služeb prostřednictvím dvoustranných franšízových smluv. V rámci této sítě poskytuje služby 2000 právně nezávislých, ale ekonomicky vzájemně propojených finančních poradců, kteři se zabývají potřebami přibližně 250000 klientů. Finanční poradci jsou př́isně koordinováni centrem sítě. Klienti jsou z velké části lékaři, zubaři, technici a ekonomové. Sít' nabízí finanční služby, zřízení životního pojištění a poradenskou činnost. Nezávislí poradci jsou sdruženi do decentralizovaných skupin, které podléhají centrálnímu vedení. Chyba $\mathrm{v}$ realizaci dlouhodobého investičního projektu jedním nezávislým poradcem zpo̊sobí klientovi velkou finanční ztrátu. Avšak chyba nemůže být v konečném důsledku přičítána finančnímu poradci, protože její přesné příčiny mají základ v obecné směrnici vydané na centrální úrovni. TEUBNER, G. Networks as Connected Contracts. Portland: Hart Publishing, 2011, s. 235. 
Ten ve své práci nabízí řešení, které je založeno na syntéze a aplikaci obecných závazkových a deliktních schémat, konkrétně institutu smlouvy s ochranným účinkem ve prospěch třetího a institutu culpa in contrahendo. ${ }^{36} \mathrm{~V}$ české právní nauce jsou odkazy na možnost aplikace těchto pravidel v zásadě fragmentární. ${ }^{37}$ Následující část se pokusí tento nedostatek napravit a uvážit, zda se nabízí interpretační východisko domácí právní úpravy, které by takovýto koncept připouštělo. Nejprve proto věnujme alespoň dílčí pozornost těmto dvěma institutům tak, jak jsou chápány a jaký je jejich teleologický podtext v německé právní nauce, nebot' v tomto právním řádu nalézáme jejich původ.

\section{Ochranné povinnosti „vlivné“ osoby - culpa in contrahendo}

\subsection{Obecná východiska}

V českém právním prostředí je institut culpa in contrahendo (CIC) spojován s předsmluvní fází kontraktace dle \1728 až \1730 OZ. Jeho dopad je však širší, a to zejména budeme-li zkoumat, jak je tato doktrína chápána a regulována v německém právním řádu. Je nutné zdůraznit, že právě odpovědnost třetích osob je stěžejním tématem, které v Německu odůvodňuje existenci institutu culpa in contrahendo a které stálo u jeho zrodu. ${ }^{38}$ Zvlášt' zde dochází k prolamování relativity závazkového právního vztahu a (smluvnî) odpovědnost je dovozována i vưči, striktně vzato, mimo stojící třetí osobě.

Německá úprava CIC, obecně obsažená v \311odst. 2 a 3 BGB, se od domácí úpravy výrazně odlišuje, přesto mám za to, že lze (a to i v domácí odborné literatuře) ${ }^{39}$ nalézt argumenty, které vedou $\mathrm{k}$ srovnatelnosti obou úprav. Předně, německé pojetí tradičně chápe předsmluvní odpovědnost jako odpovědnost smluvní, nikoliv deliktní. ${ }^{40,41}$

36 Korektní je však upozornit, že tento autor pracuje s dvěma variantami řešení. V př́padě vysoce centralizované skupiny dovozuje řešení spočívající v analogické aplikaci koncernového práva dopadajícího na kvalifikovaný faktický koncern. TEUBNER, G. Networks as Connected Contracts. Portland: Hart Publishing, 2011, s. 241 a násl.

37 S odkazem na starší německou rozhodovací praxi tuto možnost bez bližšího rozboru zmiňují KÜHN, Z. Fikce samostatnosti právnických osob a její prolomení. In: Právní roz̧bledy, 2003, č. 11, s. 542 a násl.; HÜLLE, T. Prolomení korporátního štítu aneb „konec nezávislosti osob tvořících korporátní seskupení“. In: Dny práva - 2010 - Days of Law [online]. Brno: Masaryk University, 2010 [cit. 25. 4. 2016]. Dostupné z: http://www.law.muni.cz/content/cs/proceedings; LOKAJÍČEK, J. Doktrína Piercing the Corporate Veil neboli prolomení majetkové samostatnosti právnické osoby a její možnosti v českém obchodním právu. In: Právní roz̧bledy, 2011, č. 12, s. 425 a násl.

38 HRÁDEK, J. Předsmluvní odpovědnost. In: Bulletin advokacie, 2011, č. 3, s. 48.

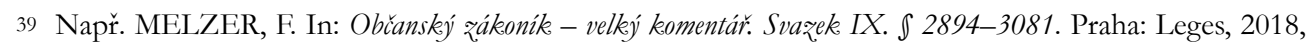
\2913, mrg. 21 a násl.

40 Doposud judikatura českého Nejvyššího soudu vycházela z deliktního pojetí předsmluvní odpovědnosti. Např: rozsudek Nejvyššího soudu ze dne 11. 10. 2006, sp. zn. 29 Odo 1166/2004, rozsudek Nejvyššího soudu ze dne 25. 9. 2007, sp. zn. 29 Odo 1335/2005, rozsudek Nejvyššího soudu ze dne 12. 7. 2010, sp. zn. 23 Cdo 724/2009.

41 Nutno ovšem poukázat na klíčové odlišnosti, které determinovaly vznik tohoto institutu v německém právním prostředí, a to zejména v odlišném pojetí odpovědnosti principála. Zásadní rozdíl je dán v okolnostech, na jejichž základě se principál může odpovědnosti zprostit. V př́padě deliktní odpovědnosti jde zejména o možnost zproštění odpovědnosti za (i nesamostatného) pomocníka dle $\int 831$ odst. 1 BGB poukazem na pečlivý výběr. (Blíže k tomto viz následující oddíl této stati.) 
V německé nauce je předsmluvní vztah chápán jako zákonný závazkový vztah, kterému je přisuzována (kvazi)smluvní povaha a který vzniká nezávisle na vůli jednajících. ${ }^{42}$ Tento závazek, který vzniká zahájením kontraktace, odráží zvláštní vztah důvěry mezi stranami. Na základě aplikace principu poctivosti (Treu und Glauben) ${ }^{43}$ dovodila německá právní věda spolu s judikaturou konkrétní obrysy tzv. vedlejších (pomocných) povinností, které jsou implikovány každému závazkovému vztahu, tedy i vztahu „předsmluvnímu." Vedlejší povinnosti jsou integrální součástí právního vztahu, kdy mají často povahu nepřímých povinností, tj. povinností, které nemohou být uplatněny přímo žalobou na plnění, nýbrž jejich porušení zakládá povinnost nahradit škodu. ${ }^{44} \mathrm{~J}$. Balarin z německé doktríny přebírá tyto př́klady: povinnost věrnosti (Treupflicht), která předpokládá, aby strany usilovaly o dosažení účelu smlouvy a nečinily nic, co by účel smlouvy ohrožovalo nebo mařilo; povinnost ochrany (Schutzpflicht), jejímž základem je respekt k právním statkům a zájmům partnera; povinnost součinnosti v zájmu dosažení účelu smlouvy (Mitwirkungspflicht); vysvětlovací povinnost (Aufklärungspflicht), tedy iniciativní informování a upozorňování partnera, kdykoli se to jeví potřebné. ${ }^{45,46}$

Korektní je upozornit, že v souvislosti s modernizací závazkového práva v roce 2002 (tzv. Schuldrechtsmodernisierung) bylo do zákonného textu přijato znění \ 241 odst. 2 BGB, ${ }^{47}$ jehož obdobu výslovně v českém občasném zákoníku nenalezneme a který zakládá ochranné povinnosti (Schutzpflichten), které působí nejen prí uzavírání smlouvy, ale po celou dobu plnění smlouvy. ${ }^{48}$

42 EMMERICH, V. Münchener Kommentar zum Bürgerlichen Gesetzbuch. 8. vyd. München: C. H. Beck, 2019, mrg. 35 a násl., \ 311; Shodně např. MATULA, Z. Culpa in contrahendo. Praha: Wolters Kluwer Česká republika, 2012, s. 9; HRÁDEK, J. Předsmluvní odpovědnost. In: Bulletin advokacie, 2011, č. 3, s. 45; či CSACH, K. Profesijná zodpovednost': zodpovednost' za škodu spôsobenú pri výkone vybraných činnosti s akecentom na europeizáciu deliketuálneho práva. Košice: Univerzita Pavla Jozefa Šafárika, 2011, s. 116 a násl.

43 Základem úpravy je $\int 242$ BGB, dle kterého „Dlužník je povinen poskytnout výkon (plnèní), ke kterému je zavázán, podle zásad dobré viry, jak je to nezbytné s obledem na obchodni zvyklosti“. Překlad převzat z TÉGL, P. Poctivost a důvěra jako jeden ze základních principů evropského smluvního práva. In: Nové jevy v právu na počátku 21. století. IV. Promèny soukromébo práva. Praha: Karolinum, 2009, s. 109 (V originále: \242 Der Schuldner ist verpflichtet, die Leistung so zu bewirken, wie Treu und Glauben mit Rücksicht auf die Verkehrssitte es erfordern).

44 MELZER, F. In: Obcáanský zákonik - velký komentár. Svaz̨ek IX. 』 2894-3081. Praha: Leges, 2018, \ 2913, $\operatorname{mrg} .14$.

45 BALARIN, J. Poznámky k (absenci) principu dobré víry v návrhu občanského zákoníku. In: Bulletin advokacie, 2011, č. 1-2, s. 25 a násl.; Cit. podle KLUNZINGER, E. Einführung in das bürgerliche Recht. München 2004, s. 183 a násl.

46 V kontextu domácí úpravy k sumarizaci ochranných povinností srov. zejm. pojem „závazkového deliktu“ podle ŠILHÁN, J. Právni následky porušeni smlouvy v novém občanském qákoníku. Praha: C. H. Beck, 2015, s. 39-40; dále např. MELZER, F. a P. TÉGL. Ob̌áanský zákoník-velký komentár. Svazęe I. \ 1-117. Praha: Leges, 2013, § 6, mrg. 60-68.

47 Závazek může rovněž v závislosti na svém obsahu zavázat každého, aby bral na zřetel práva, právní zájmy a jiné zájmy druhé strany; (vlastní překlad autora, v originále: „\$241 (2) Das Schuldverhältnis kann nach seinem Inhalt jeden Teil zur Rücksicht auf die Rechte, Rechtsgüter und Interessen des anderen Teils verpflichten").

48 Toto ustanovení tak zejména rozšiřuje ochranu nejen na zásah do absolutních práva, ale též chrání i další majetkové zájmy věřitele (Integritätsinteresse). 
Tyto ochranné povinnosti mohou překonávat relativitu závazkového vztahu a být uloženy i třetí osobě, stejně jako se jich může třetí osoba dovolávat. Př́padu, kdy je třetí osoba v pozici poškozeného, není na tomto místě nutné věnovat bližší pozornost s tím, že v tomto př́padě je na institut CIC nahlíženo jako na závazek s ochranným účinkem vůči třetí osobě, ${ }^{49}$ kterému se blíže věnuje následující oddíl. Významné jsou však případy, kdy je třetí osoba v pozici škůdce. Německá judikatura príjala odpovědnost třetích osob, pokud tyto třetí osoby využily při vyjednávání důvěry jim dané (typicky znalci, poradci) anebo pokud měly samy hospodářský zájem na výsledku, ${ }^{50}$ literatura pak doplňuje situace, kdy je odpovědnost třetích osob odůvodnitelná právě osobní angažovaností na způsobené škodě, porušením základních povinností třetí osoby nebo zneužitím vlivu této třetí osoby. ${ }^{51}$ Rozšíření dopadů předsmluvní odpovědnosti na třetí osoby našlo svůj odraz i v zákonném textu přijatého $\mathrm{v}$ rámci zmiňované novely $\mathrm{BGB}$, kdy na $\int 241$ odst. 2 BGB přímo navazuje \311 odst. 3 BGB, který prínáší pravidlo, dle kterého ochranné povinnosti ( 241 odst. 2 BGB) mohou vzniknout i ve vztahu k osobě, která není smluvní stranou za podmínky, kdy třetí osoba požívá zvláštní důvěry, a tím významně ovlivňuje jednání o smlouvě nebo uzavření smlouvy. ${ }^{52}$ Podstatné je, že podmínka (i) požívání zvláštní důvěry nebo (ii) ovlivnění jednání nebo uzavření smlouvy, jsou stanoveny jako demonstrativní a i nadále lze odpovědnost třetí osoby založit v př́padě, kdy (iii) má ekonomický zájem na uzavření či plnění smlouvy tak, jak dovodila judikatura. ${ }^{53}$

Uvedená pravidla směřují k ochraně práv a oprávněných zájmů osob a jsou základem nároku, který může vzniknout i vůči osobě, jež není smluvní stranou. Pravidlo, které v německém právním řádu přináší \ 241 odst. 2 BGB (ve spojení s \311 odst. 2 a 3 BGB), rozšiřuje ochranné povinnosti, jež doprovází každý závazek, i na třetí osoby, které tak musí jednat s respektem $\mathrm{k}$ těmto povinnostem. ${ }^{54}$

49 MARKESINIS, B. a H. UNBERATH. The German law of torts: a comparative treatise. 4. vyd. Portland, Or.: Hart Publishing, 2002, s. 704. Učebnicovým př́kladem je př́ípad odpovědnosti provozovatele zelinářství, u kterého bude založena smluvní odpovědnost za škodu, která vznikne nezletilé dceři zákaznice, pokud si způsobí újmu uklouznutím na nepečlivě ošetřené podlaze.

50 MATULA, Z. Culpa in contrahendo. Praha: Wolters Kluwer Česká republika, 2012, s. 25.

51 HRÁDEK, J. Predsmluvni odpovédnost: Culpa in contrabendo. Praha: Auditorium, 2009, s. 36.

52 Povinnost vyplývající ze závazku podle \ 241 odst. 2 může také vzniknout ve vztahu k osobám, které nejsou smluvními stranami. Takový závazek vzniká zejména v případě, kdy třetí osoba požívá zvláštní důvěry a tím významně ovlivňuje jednání o smlouvě nebo uzavření smlouvy. (Vlastní překlad autora, v originále \311 (3) BGB: „Ein Schuldverbältnis mit Pflichten nach \241 Abs. 2 kann auch zu Personen entstehen, die nicht selbst Vertragspartei werden sollen. Ein solches Schuldverbältnis entstebt insbesondere, wenn der Dritte in besonderem Maße Vertrauen für sich in Anspruch nimmt und dadurch die Vertragsverhandlungen oder den Vertragsschluss erbeblich beeinflusst.").

53 Např. rozhodnutí Bundesgerichtshof (BGH) ze dne 19. 12. 1977, II ZR 164/76 (BGHZ 70, 341), nebo rozhodnutí BGH ze dne 17. 10. 1989, XI ZR 173/88 (NJW 1990, 506).

54 TEMMING, F. Anerkennung und Grenzen eines konzerndimensionalen Kündigungsschutzes. In: Recht $\operatorname{der}$ Arbeit, 2018, č. 2, s. 96. 


\subsection{Př́ílady $z$ rozhodovací praxe zahraničních soudů}

$\mathrm{Na}$ tomto základě lze poukázat na príklady, kdy se konkrétních projevů doktríny CIC dostalo v kontextu ochrany věřitele obchodní společnosti. Jak je patrné, $v$ těchto případech došlo $\mathrm{k}$ rozšíření ochranné povinnosti i na třetí osoby. Jde např. o rozhodnutí ve věci „Patrico “55 které se v zásadě neliší od typových situací popsaných shora a představuje př́klad předsmluvní odpovědnosti tak, jak je tradičně chápána v české právní obci; $\mathrm{v}$ této věci soud založil odpovědnost mateřské společnosti, která vstoupila do vyjednávání ohledně licenční smlouvy, kdy držitelem licence měla být dceřiná společnost. Krátce před podpisem smlouvy mateřská společnost ukončila jednání, aniž by byl dán spravedlivý důvod, což vedlo ke vzniku práva na náhradu škody vưči mateřské společnosti.

Pro naše úvahy je však zajímavější judikatorní linie, která zakládá odpovědnost společníka vůči věriteli korporace na základě jeho vztahu $\mathrm{k}$ věřiteli. Ta se prosadila $\mathrm{v}$ polovině 80. let v rozhodnutích, ve kterých německý Spolkový nejvyšší soud rozvinul úvahu, dle které má jediný společník korporace, která se nachází ve finanční tísni, pokud se sám účastní jednání, povinnost informovat potencionální smluvní stranu o finanční situaci korporace. Pokud se společnost dostane do úpadku a není z toho důvodu schopna dostát svým závazkům věřiteli, zakládá porušení této ochranné povinnosti právo na náhradu škody věřitele proti společníkovi. ${ }^{56}$ Základem této povinnosti mohl být zvláštní vztah důvěry mezi společníkem a věritelem. Jisté kontroverze ${ }^{57}$ pak vzbudilo rozšíření této doktríny, která vznik ochranné povinnosti nezakládala na vztahu důvěry mezi společníkem a věřitelem, nýbrž (již) na existenci ekonomického zájmu společníka na plnění smlouvy ${ }^{58}$ Postupně $\mathrm{v}$ rozhodovací praxi došlo ke zpřesnění podmínky ekonomického zájmu nutného pro založení odpovědnosti na př́pady, kdy je vyžadován „př́mý obchodní zájem“, jako nap̌r. tehdy, pokud společník jedná jako by spravoval vlastní záležitosti. ${ }^{59} \mathrm{~V}$ tomto navazujícím rozhodnutí BGH však zdůraznil, že samo držení kontrolního podílu či potencionální výkon kontroly nad společností není dostatečnou skutečností, která by zakládala odpovědnost společníka v těchto případech. ${ }^{60}$ Odpovědnost

55 Rozhodnutí BGH ze dne 12. 6. 1975, X ZR 25/73 (NJW 1975, 1774).

56 Rozhodnutí BGH ze dne 25. 1. 1984, VIII ZR 227/82 (NJW 1984, 2284).

$57 \mathrm{~K}$ tomu např. ULMER, P. Volle Haftung des Gesellschafter/Geschäftsführers einer GmbH für Gläubigerschäden aus fahrlässiger Konkursverschleppung? In: Neue Juristische Wochenschrift, 1983, č. 29, s. 1577 a násl.

58 Rozhodnutí BGH ze dne 27. 10. 1982, VIII ZR 187/81 (NJW 1983, 676); Rozhodnutí BGH ze dne 25. 1. 1984, VIII ZR 227/82 (NJW 1984, 2284).

59 Rozhodnutí BGH ze dne 23. 10. 1985, VIII ZR 210/84 (NJW 1986, 586). Následně byly tyto závěry ve vztahu $\mathrm{k}$ osobě, která je jediným společníkem a současně čelenem statutárního orgánu společnosti s ručením omezeným revidovány v rozhodnutí BGH ze dne 6. 6. 1994, II ZR 292/91 (DNotZ 1995, 455).

60 SHIESSL, M. The Liability of Corporations and Shareholders for the Capitalization and Obligations of Subsidiaries under German Law [online]. 1986, roč. 7, č. 3, s. 480 a násl. 
mateřské společnosti může být založena pouze za výjimečných podmínek, kdy samo aktivní jednání mateřské společnosti vyvolává oprávněná očekávání věřitele a ovlivňuje okolnosti uzavření smlouvy. ${ }^{61}$

Patrně nejkomplexnější př́istup $\mathrm{k}$ aplikaci vztahu důvěry na případ propojených osob nalezneme $\mathrm{v}$ rozhodovací praxi švýcarského federálního Nejvyššího soudu. Jedná se zejména o klíčové rozhodnutí ve věci Wibru/Swissair, ${ }^{62}$ které založilo základ doktríny o existenci odpovědnosti plynoucí ze „skupinové důvěry“ (Konzernvertrauenshaftung). Skutkový základ sporu byl přibližně následující: v červenci 1987 společnost Swissair Beteiligungen AG (dále jen „Swissair “) založila dceřinou společnost IGR Holding Golf and Country Residences AG („IGR“), jež nabízela svým „členům“ time-sharingový nájem luxusního ubytování v blízkosti golfových hřrišt’ na dobu čtyřiceti let. Toto „členstvi“ v prosinci 1988 zakoupila i společnost Wibru Holding AG (dále jen „Wibru“) za cenu 90000 CHF. V únoru 1989 společnost IGR informovala své členy, že Swissair bude prodávat své akcie IGR společnosti Euroactividade AG a současně že Swissair získá menšinový podíl ve společnosti Euroactividade. Na jaře 1990 se společnost IGR ocitla $\mathrm{v}$ úpadku. $\mathrm{V}$ rozporu s předchozím oznámením společnost Swissair sice prodala své akcie IGR, avšak nezískala žádné akcie Euroactividade. ${ }^{63}$

Na tomto základě společnost Wibru uplatnila nárok na náhradu škody ve výši 90000 CHF vůči společnosti Swissair. Žalobkyně tvrdila, že IGR ve svých reklamních materiálech, ve svých dokumentech či ve styku se svými „členy“ vždy zdůrazňovala skutečnost, že je součástí skupiny Swissair a že jde o 100\% vlastněnou dceřinou společnost, která operuje za podmínek a ve standardu skupiny Swissair, a používala logo skupiny Swissair, což bylo mateřské společnosti známo. Věřitelé společnosti tak mohli důvěřovat IGR, jakožto členovi skupiny, za kterým stojí Swissair. Prodejem IGR bez poskytnutí komplexních informací ,členům“ a ponecháním IGR bez dostatečného kapitálu tak měla společnost Swissair narušit důvěru věřitelů IGR, kterou nabyli v průběhu jednání s její dceřinou společností.

Švýcarský soud nejprve uvedl, že ani z chování společnosti Swissair nelze dovodit vznik smluvní záruky (zajištěnî) vưči třetím osobám. ${ }^{64}$ Stejně tak soud odmítl úvahy o deliktní odpovědnosti společnosti Swissair. ${ }^{65}$ Připustil však, že zvláštní okolnosti ve vystupování společnosti Swissair během jednání její dceřiné společnosti se třetími osobami vytvořily zvláštní právní vztah mezi třetími osobami a Swissair, který však nebyl založen ani

61 RÖMERMANN, V. Münchener Anwaltshandbuch GmbH-Recht. 4., přepracované a rozšírené vyd. München: C. H. Beck, 2018, S 20, mrg. 227-229.

62 Rozhodnutí Bundesgericht (BGE), ze dne 15. 10. 1994, 120 II 331-341; Wibru-Holding AG/ Swissair Beteiligungen AG. Dostupné též z: http://relevancy.bger.ch/php/clir/http/index. php?highlight_docid $=$ atf $\% 3 \mathrm{~A} \% 2 \mathrm{~F} \% 2 \mathrm{~F} 120-\mathrm{II}-331 \% 3 \mathrm{Ade} \& \mathrm{lang}=\mathrm{de} \&$ type $=$ show_document

63 (BGE) 120 II 331, s. 332.

64 (BGE) 120 II 331, s. 333, 334.

65 (BGE) 120 II 331, s. 335. 
smluvně, ani deliktně. V úvahách soud vycházel ze zobecnění odpovědnostních principů culpa in contrahendo. Ve vztahu skupiny takto propojených osob je důvěra $\mathrm{v}$ bonitu člena skupiny hodna stejné ochrany, kterou požívají smluvní strany v průběhu vyjednávání. ${ }^{66}$ Třetí osoby (členové) jednaly v oprávněné důvěře v postup společnosti Swissair, která aktivně vystupovala $\mathrm{v}$ předchozích krocích a prohlášeních jako mateřská společnost. Narušení této důvěry ze strany Swissair proto může založit věřiteli právo na náhradu škody. Soud zdůraznil, že podmínky takové odpovědnosti je nutno chápat restriktivně, jako výjimku z pravidla, nebot' věřitel nemá přenášet své riziko úpadku dlužníka na mateřskou společnost a i zde se uplatní zásada caveat creditor, kdy je na věřiteli, aby správně ocenil bonitu svého dlužníka. Mateřská společnost obecně nenese odpovědnost za případný podnikatelský neúspěch dceřiné společnosti. ${ }^{67}$

Soudní dvůr dále stanovil obecné podmínky, které musí být splněny k založení tohoto druhu odpovědnosti mateřské společnosti. Ta nastává tehdy, pokud a) mateřská společnost svým jednáním založí zvláštní důvěru věřitelů v její vliv na korporaci, b) mateřská společnost tuto důvěru poruší, c) věřitel proto utrpí škodu, d) existuje prríčinná souvislost mezi porušením důvěry a škodou, jež vznikla věřiteli.

Významné je, že tyto povinnosti mateřské společnosti nelze obecně definovat; závisí na okolnostech konkrétního případu a specifických krocích mateřské společnosti. Tyto povinnosti mohou zahrnovat např́lklad i povinnost poskytnout dceřiné společnosti dostatečná aktiva $\mathrm{v}$ době vzniku či povinnosti poskytnout třetím osobám dostatečné informace týkající se dceřiné společnosti, zejména tehdy, má-li mateřská společnost v úmyslu ukončit svoji kapitálovou účast na dceřiné společnosti. ${ }^{68}$

Na uvedeném základě dospěl soud k závěru, že společnost Swissair skutečně porušila své povinnosti, když neinformovala „členy“ IGR o svých záměrech podíl v této společnosti převést na Euroactividade, aniž by získala akcie společnosti Euroactividade. Tím Swissair omezil možnost věritelů k prodeji svého „,členství “ v době, kdy společnost IGR měla ještě dostatečné prostř̌edky. Pro věc byla současně zásadní počáteční nízká kapitalizace společnosti IGR vzhledem k jejím aktivitám v rámci skupiny Swissair.

Z rozhodnutí Swissair plyne závěr, dle kterého porušení vztahu důvěry může zakládat odpovědnost jako samostatný právní důvod závazku, tedy i mimo rámec smluvního či deliktního závazku. Rozhodnutí je předmětem rozsáhlých diskusí jak ve švýcarské, tak německé nauce. ${ }^{69}$ Krom otázky správnosti celé koncepce odpovědnosti mateřské

66 (BGE) 120 II 331, s. 335.

67 (BGE) 120 II 331, s. 336.

68 (BGE) 120 II 331, s. 337.

69 Shrnutí názorových proudů $\mathrm{v}$ doktríně $\mathrm{k}$ tomuto rozhodnutí uvádí FLEISCHER, H. Konzernvertrauenshaftung und corporate advertising - ein aktueller Streifzug durch die schweizerische Spruchpraxis zum Konzernaußenrecht. In: Neue Zeitschrift für Gesellschaftsrecht, 1999, č. 15, s. 685 a násl. (NZG 1999, 685). 
společnosti je předmětem debat především otázka, jaká aktivita mateřské společnosti vede k založení tohoto zvláštního vztahu důvěry na straně jedné a jaké povinnosti z toho mateřské společnosti vyplývají na straně druhé. ${ }^{70}$

V navazujícím rozhodnutí Musikvertrieb/Motor-Columbus ${ }^{71}$ švýcarský federální Nejvyšší soud uvedenou doktrínu upřesnil. Zjednodušený skutkový základ je následující: Společnost Musikvertrieb AG uzavřela smlouvu s dceřinou společností společnosti Motor-Columbus AG, jejímž předmětem mělo být zhotovení počítači řízeného skladovacího a distribučního centra. Poté, co celý počítačový systém zcela zkolaboval, uplatnil žalobce nárok na náhradu škody vưči mateřské společnosti. Jakkoliv jsou v rozhodnutí uvažovány i jiné právní kvalifikace, zásadní je argumentační linie, jež se týká existence podmínek vzniku zvláštního vztahu důvěry vưči mateřské společnosti. Žalobce argumentoval tím, že dokumenty dceřiné společnosti obsahovaly reklamní reference, že jde o „člena skupiny Telecolumbus“. ${ }^{72}$ Sama tato skutečnost však popisovaný vztah nezakládá. Švýcarský soud při zohlednění shora uvedených závěrů rozhodnutí Swissair připomněl, že existence zvláštního vztahu důvěry přichází v úvahu pouze při naplnění striktních podmínek. Mateřská společnost nenese odpovědnost za prrípadný podnikatelský neúspěch dceřiné společnosti; ${ }^{73}$ ta přichází v úvahu pouze tehdy, pokud mateřská společnost svým jednáním vzbuzuje oprávněná očekávání druhé strany, která jsou pak nepoctivě zmařena. S ohledem na okolnosti konkrétního př́padu pouhá existence skupiny nemůže založit takovýto odpovědnostní vztah. Stejně tak ani reklamní sdělení, která obecně poukazují na skutečnost afiliace společnosti do skupiny. Naopak, zvláštní vztah důvěry předpokládá takové (aktivní) jednání mateřské společnosti, které je potencionálně způsobilé založit dostatečně konkrétní a specifické legitimní očekávání věřitele. ${ }^{74}$ Lze tedy částečně zobecnit, že uvažování o zvláštních povinnostech ve vztahu mezi věritelem a mateřskou společností je podmíněno dalšími faktory (konkrétním jednáním mateřské společnosti) než pouhou existencí skupiny. ${ }^{75}$

Korektní je však upozornit, že švýcarská doktrína odpovědnosti založené na „skupinové důvěře“ (Konz̧ernverantwortung) není v německé nauce přijímaná jednotně, kdy patrně

70 EMMERICH, V. a M. HABERSACK. Aktien - und GmbH-Konzernrecht. 9. vyd. München: C. H. Beck, 2019, \$ 302, mrg. 16.

71 Rozhodnutí Bundesgericht (BGE) ze dne 16. 4. 1998; BGE 124 III 297. Dostupné z: http://relevancy.bger.ch/php/clir/http/index.php?highlight_docid=atf\%3 A\%2F\%2F124-III-297\%3Ade \& lan$\mathrm{g}=$ de $\&$ type=show_document $\&$ zoom=OUT

72 Telecolumbus AG byla dceřiná společnost Motor-Columbus AG, která pak zanikla fúzí.

73 BGE 124 III 297, s. 304.

74 BGE 124 III 297, s. 304.

75 FLEISCHER, H. Konzernvertrauenshaftung und corporate advertising - ein aktueller Streifzug durch die schweizerische Spruchpraxis zum Konzernaußenrecht. In: Neue Zeitschrift für Gesellschaftsrecbt, 1999, č. 15 , s. 692 . 
převažují názory zdrženlivé $\mathrm{k}$ přijetí této koncepce. ${ }^{76,77} \mathrm{Z}$ citované judikatury je uváděn jediný případ, ve kterém bylo užití skupinové odpovědnosti na shora popsaném základě zvažováno, a to ve věci „Deutscher Herold“78, ve které však soud zvláštní důvody pro založení tohoto druhu odpovědnosti neshledal.

Koncept odpovědnosti pramenící ze „skupinové důvěry“ byl dokonce zpracován jako podklad jednoho z pravidel výslovné zvláštní regulace skupin společnosti a našel své výslovné legislativní vyjádření v textu \ 209 tureckého obchodního zákoníku z roku 2012.79,80

\subsection{Možnosti českého právního řádu}

Česká úprava s výslovným rozšířením předsmluvní odpovědnosti - resp. v konkrétnosti ochranných povinností - na třetí strany, které se zapojily do vyjednávání či realizace závazku, výslovně nepracuje. ${ }^{81}$ To však neznamená, že tohoto závěru nelze docílit po vzoru doktríny rakouské ${ }^{82}$ či švýcarské, která úpravu CIC neobsahuje, či s odkazem

76 Odmítavý př́stup plyne z: RIECKERS, O. Nochmals: Konzernvertrauenshaftung. In: Neue Zeitschrift für Gesellschaftsrecbt, 2007, č. 4, s. 125; RÖMERMANN, V. Münchener Anwaltshandbuch GmbH-Recbt. 4., prèepracované a rozšířené vyd. München: C. H. Beck, 2018, \20, mrg. 227-229; EMMERICH, V. Aktien - und GmbH-Konzernrecht. 9. vyd. München: C. H. Beck, 2019, \302, mrg. 17.

77 Pro prrijetí této koncepce hovoři např. BROICHMANN, A. a J. BURMEISTER. Konzernvertrauenshaftung - zahnloser Tiger oder tragfähiges Haftungskonzept? In: Neue Zeitscbrift für Gesellschaftsrecbt, 2006, č. 18, s. 687 a násl.; či FLEISCHER, H. Konzernvertrauenshaftung und corporate advertising - ein aktueller Streifzug durch die schweizerische Spruchpraxis zum Konzernaußenrecht. In: Neue Zeitscbrift für Gesellschaftsrecht, 1999, č. 15, s. 692.

78 OLG Düsseldorf, rozhodnutí ze dne 15. 7. 2005, sp. zn. 4 U 114/04 (NJOZ 2005, 3430).

$79 \mathrm{~K}$ tomu blíže např. DÜNDAR, E. Trust Responsibility Arising From Within the Companies Comunity. In: UCMA UYSAL, T. a C. ALDEMIR. Multi-level governance in developing economies. Hershey: IGI Global, 2019, s. 240 a násl.

80 Anglický překlad ustanovení zní „In cases where the controlling company attains a level where its group reputation inspires confidence among the community or consumers, it shall be liable for any consequences of such. "Předpisy dostupné z: http://www.lawsturkey.com/article/the-new-commercial-code-in-turkey

$81 \mathrm{Na}$ tomto místě je korektní podotknout, že tomu tak je patrně proto, že to nebylo v obecných typových situacích nutné, zejména za účinnosti minulé úpravy. Jde zejména o užší pojetí odpovědnosti principála dle \831 BGB ve srovnání \2914 OZ (dříve \420 odst. 2 obč. zák. 64), které v německé doktríně nutnost tohoto konceptu založilo. Viz MATULA, Z. Culpa in contrahendo. Praha: Wolters Kluwer Česká republika, 2012, s. 79; HRÁDEK, J. Předsmluvni odpovédnost: Culpa in contrahendo. Praha: Auditorium, 2009, s. 183. Nicméně je třeba vyzdvihnout, že \2914 OZ je aplikačně užší, než byl chápán \420 odst. 2 obč. zák. 64, kdy zejména $\mathrm{v}$ př́padě samostatného pomocníka je otázka aplikačního rozsahu stále otevřená. Nadto typové situace, o kterých je uvažováno $\mathrm{v}$ kontextu této stati, aplikaci odpovědnosti principála dle \2914 odst. 1 věta první OZ vylučují.

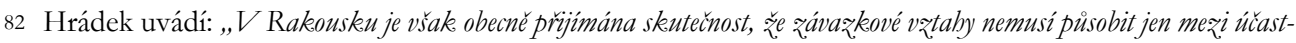

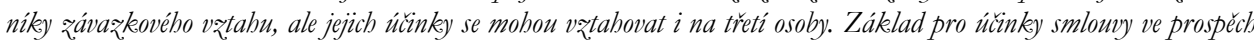

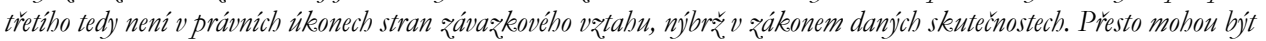

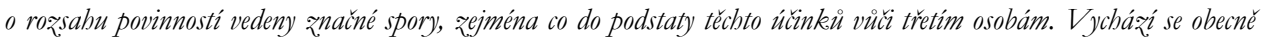

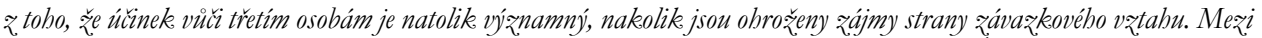
tyto zájmy pak patrǐ zejména ochrana majetku a zdraví, ale té̌̌ tretich osob samotných. "HRÁDEK, J. Předsmluvní odpovědnost. In: Bulletin advokacie, 2011, č. 3, s. 48. 
na rozhodovací činnost výše uvedených německých soudů tak, jak byla formulována před reformou závazkového práva. ${ }^{83}$

Ostatně tato paralela do značné míry kopíruje úvahy o smluvním či deliktním základě předsmluvní odpovědnosti a ani druhý závěr možnost uplatnění porušení ochranných povinností vưči třetí osobě nevylučuje. K tomu uvádí M. Hulmák ,jestliže je predsmluvní odpovédnost postavena v zásadě na porušeni zákonné povinnosti jednat v objektivni dobré vire bez vazby

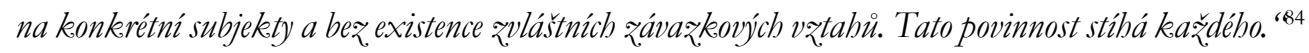
Je tedy otázkou, zda česká právní nauka a praxe přijme výklad ustanovení \ 1728 až $\int 1730$ OZ, resp. výchozího $\int 6$ OZ ${ }^{85}$, jenž odráží německou zkušenost a který je konstruován na myšlence, že jde o skutečně existující právní vztah naplněný konkrétními povinnostmi, ${ }^{86}$ nebo budou tato ustanovení chápána ,jen“ jako konkrétní projev zákonné povinnosti nepoškozovat jiného. ${ }^{87} \mathrm{~V}$ obou př́padech je však základem odpovědnosti narušení principu poctivosti dle $\int 6 \mathrm{OZ}$ a jeho doplňující, ale i korigující funkce, kdy shora popisované př́pady lze typově podřadit pod narušení principu poctivosti označované jako venire contra factum proprium. ${ }^{88} \mathrm{~V}$ obou př́padech platí, že každý má povinnost postupovat poctivě a nesmí těžit nejenom z vlastního protiprávního či nepoctivého činu, ale ani z protiprávního stavu, nad kterým má kontrolu (\$6 OZ). Stejně tak každý musí postupovat způsobem, který nepůsobí bezdůvodně újmu druhým ( 3 odst. $1 \mathrm{OZ}$ ), a snažit se dle okolností konkrétního případu předcházet vzniku škody ( 2900 OZ), popř́padě proti vzniku škody i zakročit (\$ 2901 OZ).

Pro následující rozbor je zásadní dílčí závěr, dle kterého i v českém právním řádu jsou odvoditelné ochranné povinnosti, ${ }^{89}$ které se váží ke konkrétnímu závazku a které odráží existenci zvláštního vztahu důvěry mezi stranami. Konstrukce těchto povinností

83 Tak např. dílčí úvahy o využitelnosti institutu culpa in contrahendo lze nalézt např. rozsudku Nejvyššího soudu ze dne 20. 12. 2007, sp. zn. 29 Odo 1673/2005.

84 HULMÁK, M. Limity předsmluvní odpovědnosti. In: Bulletin advokacie, 2011, č. 3, s. 55.

$85 \mathrm{~K}$ tomu obecně např. TÉGL. P. Poctivost a důvěra jako jeden ze základních principů evropského smluvního práva In: Nové jevy v právu na poćátku 21. století. IV. Promény soukromého práva. Praha: Karolinum, 2009, s. 99 a násl.

86 Názor zastávaný především HRÁDEK, J. Předsmluvni odpovédnost: Culpa in contrahendo. Praha: Auditorium, 2009, s. 183; či MELZER, F. In: Občanský zákoník - velký komentár. Svazuek IX. \ 2894-3081. Praha: Leges, 2018, ऽ 2913, mrg. 28.

87 BŘÍZA, P. a T. PAVELKA. In: PETROV, J. a kol. Občanský qákoník. Komentár. Praha: C. H. Beck, 2017, s. 1664; HULMÁK, M. Limity předsmluvní odpovědnosti. In: Bulletin advokacie, 2011, č. 3, s. 54; či PELIKÁNOVÁ, I. a R. PELIKÁN. In: ŠVESTKA, J. a kol. Občanský qákoník: komentár. Svazek. V,

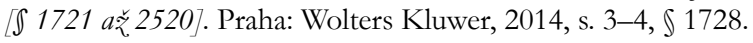

88 Blíže k tomu např. LAVICKÝ, P. In: Občanský zákoník I. Obecná část (』 1-654). Komentár. 1. vyd. Praha: C. H. Beck, 2014, s. 72-81.

89 Např. ŠILHÁN, J. Právni následky porušeni smlouvy v novém ob̌́anském zákoníku. Praha: C. H. Beck, 2015, s. 39-40; NOVÝ, Z. Dobrá víra jako princip smluvního práva v mezinárodním obchodu. Praha: C. H. Beck, 2012, 207 s.; MELZER, F. a P. TÉGL. In: Občanský zákoník - velký komentár. Svazek I. \ 1-117. Praha: Leges, 2013, § 6, mrg. 60-68. 
zapovídá osobám, jež mají faktickou blízkost k závazku, „externě“ intervenovat do jeho vzniku či trvání takovým zpo̊sobem, který by poškozoval smluvní stranu. ${ }^{90}$ Domnívám se proto, že ani domácí právní úprava nevylučuje přijetí konceptu culpa in contrahendo ve vztahu $\mathrm{k}$ třetím osobám, tak jak byl rozpracován $\mathrm{v}$ německé nauce a který je založen na zvláštním vztahu důvěry (sachwalterhaftung), ${ }^{91}$ Odpovědnými subjekty nemusí být nutně jen smluvní strany, ale též osoby stojící mimo závazek, a to bud' na základě aplikace doktríny culpa in contrahendo, tak jak bylo popsáno shora, anebo na základě obecných principů poctivosti a neminem leadere, které jsou však i pro tuto třetí osobu subjektivizovány a konkretizovány v případě, kdy osoba požívá zvláštní důvěry ze strany kontrahenta nebo má vlastní kvalifikovaný ekonomický zájem na tomto závazku, resp. aktivně do závazku intervenuje.

V kontextu ochranných povinností pramenících ze vztahu důvěry F. Melzer a P. Tégl trefně hovoří o zvláštním „mikrosvětě“, v němž existují specifické druhy povinností, zejména obecná povinnost loajality vưči smluvnímu partnerovi, která se projevuje nutností brát v úvahu oprávněné zájmy a legitimní očekávání druhého. ${ }^{92}$ Mám za to, že lze nacházet dobré důvody, kdy je tento „mikrosvět“ rozšířen za hranice relativity závazku a je do něj „vtažena“ i mateřská společnost, pokud se na závazku aktivně podílí v limitech shora popsaných. Pro posouzení, kdy je dán tento zvláštní vztah blízkosti, který odůvodňuje uložení ochranných povinností třetí osobě, lze vyjít analogicky z aplikačních podmínek smlouvy s ochranným účinkem ve prospěch třetího.

\section{Smlouvy s ochranným účinkem ve prospěch třetího}

Důvod, proč má smysl uvažovat o aplikačních podmínkách smlouvy s ochranným účinkem ve prospěch třetího v kontextu probíraného tématu, je dvojí. Zaprvé, výslovná úprava \2913 OZ, jež je obecným východiskem tohoto institutu v účinné právní úpravě, představuje př́klad, kdy zákonodárce výslovně připouští podmínky prolomení relativity závazkového právního vztahu. Obdobně jsou i při zde dovozované odpovědnosti mateřské společnosti posuzovány situace, kdy rozšiřujeme ochranou sféru závazku na formálně vzato - osoby stojící mimo něj. Lze předpokládat, že v obou př́padech jde o projev obdobných hodnot a zásad soukromého práva, a proto je na místě zkoumat, s jakými podmínkami zákon překonání relativity závazkového právního vztahu de lege

90 Širší obsah závazku ostatně vyplývá i z textace $\int 545$ OZ, dle kterého „Právní jednání vyvolává právní následky, které jsou v nèm vyjádřeny, jakož i právni následky plynouci ze zákona, dobrých mraví, zvyklostí a zavedenépraxe stran. "

91 EMMERICH, V. Münchener Kommentar zum Bürgerlichen Gesetzbuch. 8. vyd. München: C. H. Beck, 2019, § 311, mrg. 193, 194.

92 Tito autoři hovoří i o tom, že povinnost poctivosti nepůsobí jen v rámci obligace, ale může být založena i jinou právní poctivostí, je-li pro to dán zvláštní důvod. Blíže viz MELZER, F., P. TÉGL a kol. Občanský

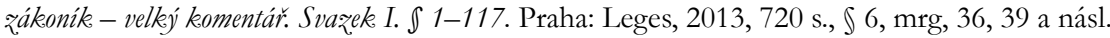


lata spojuje. Tyto předpoklady následně mohou sloužit jako interpretační vodítko při posuzování odpovědnosti mateřské společnosti.

Ostatně př́padná aplikace předpokladů smluv s ochranným účinkem ve prospěch třetích osob v kontextu propojené korporátní skupiny není jediným prríkladem, kdy tento právní institut slouží k posílení ochrany poškozeného v př́padech, kdy je vznik škody spojen s činností osoby stojící mimo závazkový právní vztah. Zadruhé, lze proto upozornit, že to byla právě doktrína smlouvy s ochranným účinkem ve prospěch třetích osob, která vytvořila jednu z argumentačních linií pro založení odpovědnosti výrobce za škodu způsobenou vadou výrobku; ${ }^{93,94} \mathrm{v}$ současnosti je pak o využití konceptu smlouvy s ochranným účinkem (resp. smlouvy ve prospěch třetí osoby) uvažováno v kontextu odpovědnosti korporace vykonávající vysokou míru kontroly v dodavatelsko-odběratelských vztazích. ${ }^{95,96}$ Ačkoliv konkrétní důvody pro rozšíření ochranné sféry závazku v těchto případech jsou velmi specifické, lze nalézt jistou podobnost s př́pady zde posuzovanými, kdy je závazkový právní vztah dotčen výkonem vlivu, jež je uplatňován vůči jedné ze smluvních stran. $\mathrm{V}$ českém právním prostoru byla doposud institutu smlouvy s ochranným účinkem ve prospěch třetího věnována pouze okrajová pozornost. ${ }^{97}$ Judikatura vztahující se k občanskému zákoníku 1964 nicméně přijala závěry, které se této doktríně přibližují. ${ }^{98}$

93 K německé a francouzcské historické zkušenosti srov. např.: WAGNER, G. The Development of Product Liability Law in Germany. In: WHITTAKER, S. The development of product liability. New York: Cambridge University Press, 2010, s. 122 a násl.; BORGHETI, J. S. The Development of Product Liability in France. In: WHITTAKER, S. The development of product liability. New York: Cambridge University Press, 2010, s. 95 a násl.

94 De lege lata jde o úpravu \2939 a násl. OZ, jenž je transpozicí směrnice Rady 85/374/EHS o sbližování právních a správních předpisů členských států týkajících se odpovědnosti za vadné výrobky ze dne 25. července 1985.

95 Jde zejména o silně exponovaný prrípad možné odpovědnosti německého oděvního retězce KiK TextilienGmbH, v souvislosti s tragickým požárem v továrně Karachi v Pakistanu, kterou provozovala dodavatelské společnost Ali Enterprises. Blíže k tomu nap̌r.: HEINLEIN, I. Zivilrechtliche Verantwortung transnationaler Unternehmen für sichere und gesunde Arbeitsbedingungen in den Betrieben ihrer Liefe-ranten. In: Neue Zeitschrift für Arbeitsrecht, 2018, č. 5, s. 276 a násl.

96 Dále k tomu např. ULFBECK, V. Supply Chain Liability for Workers’ Injuries - Lessons to be Learned from Products Liability? In: Journal of European Tort Law [online]. 2018, roč. 9, č. 3, s. 275 a násl.

97 Kromě dále citovaných zejména: ŠILHÁN, J. Právni následky porušeni smlouvy v novém občanském zákoníku. Praha: C. H. Beck, 2015, s. 39-40; či CSACH, K. Profesijná zodpovednost': zodpovednost' za škodu spôsobenú pri výkone vybraných činnostís akecentom na europeizáciu deliktuálneho práva. Košice: Univerzita P. J. Šafárika, 2011, s. 111 a násl.

98 Bylo tak judikováno, že „závèr, podle kterého se poškozený mưže dovolávat (za účelem prokáááni existence protiprávního úkonu) porušeni smluvni povinnosti, totiž lze učinit nejen v prǐpadě, že je škưdcovým spolukontrahentem (drubou smluvni stranou). K naplnèni uvedeného prèdpokladu postačuje, že je prokázáno, že prǔslušný subjekt (škĩdce) sice porušil povinnost ze smlouvy, kterou uzavrel s jinou osobou než s poškozeným, že však závazek, k jehož porušeni došlo, mél dopad do právni sféry poškozeného. Takovému závèru prìtom neni na prekéažku ani skutečnost, že smlouva, z ní̌porušeni

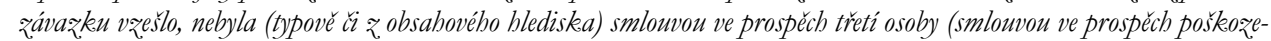
nébo). Jinak réceno, podstatné je, že byla porušena právni povinnost, která (byt’ prostrednictvím smluvního ujednání jüných osob) slouřila ke ochraně subjektivnich práv poškozenébo. "Rozsudek Nejvyššího soudu ze dne 25. 3. 2003, sp. zn. 29 Odo 378/2001, obdobně pak např. v rozsudku Nejvyššího soudu ze dne 29. 7. 2008, sp. zn. 25 Cdo $1417 / 2006$. 
Je však pravdou, že vzhledem k jednotnému pojetí deliktu v úpravě občanského zákoníku 1964 velký význam tato doktrína neměla, nebot' typové situace, k jejichž řešení institut smlouvy s ochranným účinkem ve prospěch třetího souží, bylo možno řešit na základě povinnosti k náhradě škody pro porušení zákonné povinnosti dle $\int 415$ obč. zák. 1964. V tomto směru občanský zákoník z roku 2012 přinesl významnou změnu. Výslovně připouští možnost rozšíření ochranného účelu smlouvy i na třetí osoby $\mathrm{v}$ př́ípadech (obecně) předvídaných v \2913 OZ, tedy tehdy, pokud třetí osobě mělo splnění ujednané povinnosti, která byla porušena smluvní stranou (škůdcem), zjevně sloužit.

Hlavní myšlenka této konstrukce spočívá v tom, že pokud při plnění smluvní povinnosti vznikne škoda též osobě, která není smluvní stranou, může (jinak) tato osoba požadovat náhradu škody pouze za podmínek deliktní odpovědnosti. Úskalí tohoto závěru v kontextu německé právní úpravy byla již $\mathrm{v}$ zásadě popsána $\mathrm{v}$ předešlé části. Jde zejména o možnost zproštění se odpovědnosti, způsobil-li škodu tzv. pomocník (např. zaměstnanec), jestliže principál prokáže náležitou péči při výběru dle $\int 831 \mathrm{BGB}$. V tomto př́padě by poškozenému, který není smluvní stranou, náleželo pouze právo na náhradu škody pro porušení zákonné povinnosti vůči pomocníkovi. ${ }^{99}$ Tento problém úprava občanského zákoníku nezná, nebot' \ 2914 OZ, věta první, zachovává plnou odpovědnost principála za (nesamostatného) pomocníka $\mathrm{i} v$ př́padě deliktní odpovědnosti. ${ }^{100}$ Nicméně, a to je třeba vyzdvihnout, pokud uvažujeme o aplikaci této doktríny v kontextu funkčně propojených osob (skupiny společnostî), pak mezi propojenými osobami pravidelně není vztah, který by odpovídal povaze nesamostatného pomocníka. Na tomto půdorysu má význam uvažovat o možnosti rozšśření ochranného účelu smlouvy vůči třetí osobě smysl i v kontextu probírané problematiky.

$\mathrm{V}$ režimu českého právního řádu získává tato doktrína na důležitosti dále $\mathrm{v}$ tom, že umožňuje poškozené třetí osobě požadovat náhradu čisté majetkové škody, jejíž plnění by v režimu dle \2910 OZ bylo (v zásadě) omezeno na případy zásahu do absolutních práv. ${ }^{101}$

Pro další úvahy je nutné alespoň ve stručnosti shrnout předpoklady, za kterých lze o rozšírení ochranného účelu smlouvy uvažovat: ${ }^{102}$

a) Blízkost plnění, proximita: tou je uvažována blízkost třetí osoby k plnění, které má být dle smlouvy poskytnuto. Ta je dána tehdy, má-li třetí osoba dle účelu smlouvy zájem na plnění. Vychází se z myšlenky, že v těchto př́ípadech je třetí osoba vystavena

99 Van DAM, C. European tort law. 2. vyd. Oxford: Oxford University Press, 2013, s. 505.

100 Byt' i zde je dána podmínka zavinění. MELZER, F. In: Občanský quákoník - velký komentár. Svazek IX. 〔 2894-3081. Praha: Leges, 2018, \2913, mrg. 83.

101 MARKESINIS, B. a H. UNBERATH. The German law of torts: a comparative treatise. 4. vyd. Portland, Or.: Hart Publishing, 2002, s. 59.

102 LOOSCHELDERS, D. Schuldrecht: Allgemeiner Teil. 2., přepracované vyd. Köln: Carl Heymanns Verlag, 2004, mrg. 204 a násl. 
stejnému riziku plynoucímu ze smlouvy, jakému je vystaven kontrahent. Pod tento požadavek jsou zahrnuty i př́pady, ve kterých nejde o blízkost plnění v pravém slova smyslu, kdy smlouvou zamýšlený účinek může mít dopad pro třetí stranu. ${ }^{103}$

b) Zájem kontrahenta na zahrnutí této třetí osoby do ochranné sféry závazku: Obecněji lze tuto podmínku chápat jako existenci úzkého vztahu mezi věritelem a třetí osobou. ${ }^{104}$ Tradičně jsou uváděny př́klady, kdy je věřitel na základě právního poměru spoluodpovědný za tzv. „blaho a bídu“ (Wobl und Wehe) třetího (např. vztah otec a syn). ${ }^{105}$ Melzer však upozorňuje, že v některých př́padech tento požadavek vyžadován není a hranice tohoto předpokladu nejsou dosud zcela jasné. ${ }^{106,107}$

c) Zjevnost, rozpoznatelnost pro dlužníka: zájem třetí osoby musí být seznatelný pro škůdce. I na jeho straně musí být dána možnost ohodnotit toto riziko. Nejde o přesnou znalost konkrétního třetího subjektu, ale o podmínku (abstraktního) rozpoznání okruhu osob, jež mohou být jednáním škůdce dotčeny. Není proto vyloučeno, aby do ochranné oblasti smlouvy bylo zahrnuto velké množství osob.

d) Potřeba zvláštní ochrany třetí osoby: ${ }^{108}$ ta odpadá v případě, kdy třetí osoba má vlastní smluvní nárok vůči dlužníkovi či třetí osobě. Melzer uvádí, že „na potrebě tohoto kritéria nic nemèni ani skutečnost, že smluvni partner tretí osoby je insolventni; pravidla o smlouvě s ochranným účinkem vioù tretím osobám nemaji odejmout insolvenčni riziko, keteré třetí

103 GOTTWALD, P. In: Münchener Kommentar zum Bürgerlichen Gesetz̧buch. 8. vyd. München: C. H. Beck, 2019, $\int 832$.

104 Jde např. i o vztah mezi společníkem a společností, kdy byl uznán nárok společníka na náhradu škody proti daňovému poradci (škůdce), který nesprávně vyhodnotil hospodářskou situaci společnosti (věřitel), která následně z toho důvodu nepodala včas insolvenční návrh. (Rozhodnutí BGH, sp. zn. IX ZR 145/11). Nebo rozhodnutí, které založilo právo společníka vưči advokátovi (škůdce), který uzavřel smlouvu se společností (věřitel) a následně poskytl nesprávnou radu ohledně kapitalizace pohledávky společníka za společnosti. Společníci tak v rozporu se zákonem pohledávku vložili jako peněžitý vklad nikoliv jako nepeněžitý, což zakládalo povinnost k náhradě škody. (Rozhodnutí BGH ze dne 2. 12. 1999, sp.zn. IX ZR 415/98). Obecně k tomu EMMERICH, V. Münchener Kommentar zum Bürgerlichen Gesetz̧buch. 8. vyd. München: C. H. Beck, 2019, 』 311, mrg. 193, 197, 198.

105 KOLMAČKA, V. Úvod ke smlouvě s ochrannými účinky ve prospěch třetího v české právní úpravě. Iurium [online]. Publikováno 13. 12. 2017 [cit. 14. 6. 2019]. Dostupné z: https://www.iurium.cz/2017/12/13/ smlouva-ochranne-ucinky/\#_ftn43

106 MELZER, F. In: Občanský zákoník - velký komentár. Svazek IX. \ 2894-3081. Praha: Leges, 2018, \2913, mrg. 65. Blíže tyto pochybnosti rozebírá MARKESINIS, B. a H. UNBERATH. The German law of torts: a comparative treatise. 4. vyd. Portland, Or.: Hart Publishing, 2002, s. 62.

107 Sporným př́kladem je zejména odpovědnost znalců či odborníků, kteří za úplatu poskytují posudek jedné ze smluvních stran. Kontroverzní je otázka, zda povinnosti nahradit škodu způsobenou nesprávností takového posudku může domoci i druhá smluvní strana, která ke znalci nebyla ve smluvním vztahu v př́ípadě, kdy druhé smluvní straně z vypracování nesprávného posudku škoda nevzniká. Např. Rozhodnutí BGH ze dne 10. 11. 1994, sp. zn. III ZR 50/94.

108 Některé zdroje tento čtvrtý předpoklad nutně nezahrnují. Viz MARKESINIS, B. a H. UNBERATH. The German law of torts: a comparative treatise. 4. vyd. Portland, Or.: Hart Publishing, 2002, s. 63 a zdroje zde citované. 
osoba nese vǐci svému smluvnímu partneru. "109 Jde o projev obecnější a výše zmiňované zásady Caveat creditor. Nicméně, uvažujeme-li o přenosu tohoto pravidla do kontextu skupiny propojených osob, lze uvažovat o překlenutí této podmínky, nebot' smluvní nárok vůči dlužníkovi (resp. neschopnost jeho uspokojení) je zde dotčen výkonem vlivu. ${ }^{110}$ Relativita závazkového právního vztahu je dotčena výkonem vlivu již na svém „vstupu“. ${ }^{111}$ Existence kvalifikovaného vlivu - tak, jak je o něm pojednáno dále - se proto jeví jako dostatečný důvod pro prolomení relativity závazkového vztahu i na „výstupu“, v kontextu jeho porušení. Je to právě jednání vlivné osoby (typicky dominantního společníka, mateřské společnosti), které v těchto prrípadech obvykle zakládá důvod pro nemožnost věritele žádat uspokojení přímo po společnosti, či se na něm alespoň kvalifikovaně podílí. Tedy jinými slovy, je to právě jednání vliv vykonávající osoby, které deformuje insolvenční riziko na straně dlužníka. Za těchto okolností lze uvažovat o potřebě ochrany třetí osoby - věritele korporace i tehdy, má-li věřitel formálně vzato samostatný nárok vůči ovlivněné korporaci.

$\mathrm{V}$ kontextu této stati bude dále uvažováno o možnosti, zda mezi propojenými osobami (tedy ve vztazích existujících uvnitř skupiny společnostî) lze nalézt takovou intenzitu vztahů, jejîž narušení může mít dopad i do sféry věřitele jedné z korporací. ${ }^{112}$ Jistá podobnost této situace se nabízí s případy, které posuzovaly německé soudy v souvislosti s odpovědností bankovních domů při provádění bezhotovostních operací klienta, ve kterých byl přijat názor, že smlouvy mezi bankovními ústavy mohou představovat smlouvy s ochranným účinkem vůči klientovi. ${ }^{113}$

Odborná literatura k \2913 odst. 1 OZ vyslovuje v zásadě jednotný názor o využitelnosti shora naznačených podmínek v české právní úpravě. ${ }^{114}$ Při splnění těchto kritérií jsou ochranné povinnosti závazku rozšířeny i na třetí osobu a té náleží samostatné právo na náhradu škody způsobené jejich porušením. Textaci \ 2913 odst. 1 OZ je spíš než

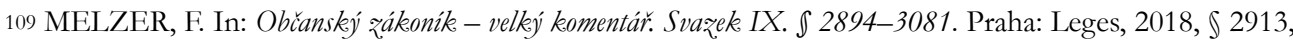
mrg. 69.

$110 \mathrm{~V}$ kontextu existence zvláštního vztahu důvěry k tomu: BROICHMANN, A. a J. BURMEISTER. Konzernvertrauenshaftung - zahnloser Tiger oder tragfähiges Haftungskonzept? In: Neue Zeitschrift für Gesellschaftsrecht, 2006, č. 18, s. 691.

111 Blíže je o důvodech dotčení relativity závazku výkonem vlivu a následcích z toho plynoucích pojednáno v následujícím oddíle této stati.

112 K otázce omezené možnosti posuzovat vztah mezi společníkem a právnickou osobou za vztah s ochranným účinkem vůči třetí osobě viz GOTTWALD, P. In: Münchener Kommentar zum Bürgerlichen Gesetz̧buch. 8. vyd. München: C. H. Beck, 2019, \832, mrg. 72-74.

113 Např̀. rozsudek BGH, ze dne 23. 9. 1985, II ZR 172/84 (NJW 1986, 249); Nutno však zdůraznit, že tento závěr byl revidován rozhodnutím BGH, ze dne 6. 5. 2007, XI ZR 56/07 (NJW 2008, 2245). Tento posun byl částečně předurčen změnou úpravy a zařazením \676a a násl BGB, který tyto situace reguluje.

114 Krom zmiňovaného F. Melzera, dále shodně: BEZOUŠKA, P. In: HULMÁK, M. a kol. Občanský zákoník VI. Závazkové právo. Zvlástni cást (』 2055-3014). Komentár. 1. vyd. Praha: C. H. Beck, 2014, s. 1565-1576; či ŠILHÁN, J. Právni následky porušeni smlouvy v novém občanském zákoníku. Praha: C. H. Beck, 2015, s. 305-306. 
jako komplexní úpravu třeba chápat jako výzvu zákonodárce k možnosti interpretačního rozšíření ochranného účelu smlouvy na další osoby. Z této myšlenky vychází i navazující úvahy, ve kterých nejde o prímou aplikaci této doktríny, ale o využití totožných principů, jež institut smlouvy s ochranný účiníkem ve prospěch třetího zrcadlí, ve specifických situacích. Na závěr je nutné ještě jednou zdůraznit, že smlouvou s ochranným účinkem ve prospěch třetí osoby, na smlouvě nezúčastněné, se jí otevírá možnost dovolat se vedlejších (ochranných) povinností. ${ }^{115} \mathrm{Za}$ určitých podmínek mohou být třetí osobě založeny pouze povinnosti ochrany (Schutzpflichten), ${ }^{116}$ tak jak o nich bylo pojednáno shora, aniž by jí vznikl nárok na hlavní plnění, jako např. dle smlouvy ve prospěch třetího dle \1767 OZ.

\section{Syntéza}

\subsection{Ochranné schéma smluvního věřitele - vstupní úvahy}

Zdá se, že při hledání řešení ochrany věřitele skupiny propojených osob na půdorysu těchto dvou institutů narážíme na kompatibilitu s logikou vnitřní a vnější strukturalizace vztahů skupiny. Oba odpovědnostní modely totiž vychází z prolomení relativity závazkového vztahu v kontextu, „izolovaně“ (samostatně) pojímaného závazku mezi dlužníkem a věřitelem. V námi popisovaném př́padě je však struktura vztahů dvojí. Smlouva s ochranným účinkem vưči třetí osobě kopíruje usuzování relace mezi propojenými osobami, at' již uvažujeme o rovině mateřská - dceřiná společnost či jiné formě integrace založené např. na smluvní bázi, tak jak o nich bylo pojednáno v úvodní části této stati. Oproti tomu možnosti, které přináší institut culpa in contrahendo $\mathrm{k}$ třetím osobám by vycházely z „vnějšího“ vztahu, tedy vztahu mezi věřitelem a korporací, na niž další osoba uplatňuje určitou formu vlivu.

Shora citovaný G. Teubner nachází řešení na základě syntézy obou těchto nástrojů, avšak pouze $\mathrm{v}$ rozsahu, který odpovídá specifikům smluv uzavíraných s osobami vzájemně ekonomicky provázanými. Jeho úvaha o aplikaci obou nástrojů je taková, že vhodné řešení je třeba hledat ve vzájemném propojení doktríny smlouvy s ochrannými účinky pro tretí osobu a culpa in contrahendo: „Zatímco posledně jmenovaný institut ukládá povinnosti ostatním clenuim skupiny, které intervenuji do závazku s treti osobou, smlouva s ochrannými úcinky poskytuje tretí osobè status vérítele členù skupiny. Na první pobled by tyto dvě konstrukce mohly být snadno zamènèny. To však neplatí, protože kritéria pro uloženi povinnosti jsou v obou přpadech konstruována odlišnè. Smlouva s ochrannými účnky pro tretí osobou definuje svá keritéria s odkazem

115 MARKESINIS, B. a H. UNBERATH. The German law of torts: a comparative treatise. 4. vyd. Portland, Or.: Hart Publishing, 2002, s. 59.

116 MELZER, F., In: Obíanský zákoník - velký komentár. Svazek IX. \2894-3081. Praha: Leges, 2018, \2913, mrg. KOLMAČKA, V. Úvod ke smlouvě s ochrannými účinky ve prospěch třetího v české právní úpravě. Iurium [online]. Publikováno 13. 12. 2017 [cit. 14. 6. 2019]. Dostupné z: https://www.iurium. cz/2017/12/13/smlouva-ochranne-ucinky/\#_ftn43 
na vątaby, které jsou interní ve skupině propojených osob. Culpa in contrabendo definuje svá kritéria s obledem na (vnèjsí) smlouvu s tréti osobou a z této pozice se snaži ukládat povinnosti ostatním členuim skupiny. Rozdil mezi povinnostmi vyplývajicimi ze vatabu wnitr skupiny a ze smlouvy s vnè stojicím verritelem je stálým nebezpečm v celé konstrukci. S touto kolizi nelze bojovat pouze z.pobledu pruního či drubébo vatabu. Vhodným rèsenim je kombinace obou perspektiv a kritérii závazkè vĩci tretím stranám stanovených každou z nich. " "117

Syntéza výše uvedených poznatků toto řešení nabízí. Podstatné pro tyto úvahy je, že institut culpa in contrahendo je ve své podstatě právním odrazem hodnotového základu, který je vyjádřen myšlenkou, že pokud jakákoliv osoba (v námi uvažovaném kontextu jde o osobu vykonávající vliv na smluvní stranu) vstoupí do blízkého kontaktu (faktického vztahu) s věritelem, je nutno jejich vzájemný vztah více subjektivizovat, a to zejména s ohledem na požadovanou úroveň chování a výkon práv v souladu s principem poctivosti a vzájemné důvěry. Jedním z klíčových elementů takového vztahu je povinnost zabránit škodě, která by mohla vzniknout druhé straně a která by byla v prŕčinné souvislosti s jednáním strany vázané takovou povinností. ${ }^{118}$

Závazkový právní vztah, který je takto „ovlivněn“ vnější třetí osobou (je ve sfére jejího vlivu či kontroly), nabourává doktrinální východiska autonomie vůle ${ }^{119}$ vyjádřené tím, že strany mohou jednat nezávisle. Důvodem této asymetrie je konstrukce vztahu, který je projevem výkonu vlivu jedné osoby na druhé. Avšak tato nesouměrnost může ovlivnit též vnitřní rovnováhu závazku, jenž vzniká mezi osobou vlivem dotčenou a osobou další (věritelem), a to na náklady strany, která tímto vlivem dotčena přímo není. ${ }^{120} \mathrm{~K}$ překlenutí tohoto napětí se jako nejvhodnější nástroj řešení jeví využití těch institutů, které vznikly právě $\mathrm{v}$ reakci na existenci vnějších vztahů $\mathrm{k}$ závazku a které reflektují možné zájmy třetích osob na vznik, formování a trvání závazku smluvních stran. Jak bylo uvedeno, jedním $\mathrm{z}$ těchto nástrojů je právě institut culpa in contrahendo ve vztahu k třetím osobám.

První logický problém, který vyvstává ve snaze aplikovat doktrínu culpa in contrahendo ve spojitosti se skupinou propojených osob, je nasnadě. Tradičně je tento koncept „předsmluvni““ odpovědnosti uplatněn na situace vycházející z „předkotraktačni“ fáze. Nabízí se otázka, zda lze zásady odpovědnosti třetích osob rozšírit pro př́pady následného porušení závazku. Srovnatelná povaha rozložení zájmů před a po uzavření smlouvy hovoři ve prospěch takového rozšíření. ${ }^{121}$ Dle této úvahy mưže povinnost $\mathrm{k}$ náhradě

117 Volně parafrázováno v kontextu probírané problematiky dle: TEUBNER, G. Networks as Connected Contracts. Portland: Hart Publishing, 2011, s. 77 a násl.

118 HRÁDEK, J. Předsmluvní odpovědnost. In: Bulletin advokacie, 2011, č. 3, s. 46-47.

119 Striktní výklad narušení smluvní autonomie uvádí: RIECKERS, O. Nochmals: Konzernvertrauenshaftung. In: Neue Zeitschrift für Gesellschaftsrecht, 2007, č. 4, s. 128.

120 TEMMING, F. Anerkennung und Grenzen eines konzerndimensionalen Kündigungsschutzes. In: Recht der Arbeit, 2018, č. 2, s. 95.

121 TEUBNER, G. Networks as Connected Contracts. Portland: Hart Publishing, 2011, s. 77 a násl. 
škody pro zásah do ochranné povinnosti stíhat ty subjekty, které požívají důvěry v naplnění účelu smlouvy a jejichž ekonomické zájmy jsou smlouvou úzce dotčeny.

Obecně jde o případy, kdy smluvní strana (věřitel) vstupuje do vztahu s osobou, která je zapojena do širší skupiny společností takovým způsobem, že plnění závisí i na dílčích krocích či jednáních dalších členů skupiny. V těchto př́ipadech nacházíme nástroje prolamující relativitu závazkového právního vztahu, jestliže je realizace závazku stranou, která je členem této skupiny, dotčena jednáním jiné osoby s ní úzce propojené. Jakkoliv je v české rozhodovací praxi patrná zdrženlivost v otázce prolamování relativity závazkového vztahu na půdorysu propojených osob, ${ }^{122}$ lze předpokládat, že realita nového občanského zákoníku úvahu o odpovědnosti vyplývající z vlivu a kontroly připouští.

\subsection{Aplikační předpoklady}

Prvotní podmínkou možného odpovědnostního schématu je proximita, tedy blízkost. Tou v těchto situacích myslíme skutečnost, že okolnosti vztahu mezi propojenými osobami mohou mít dopad do sféry věritele. Vycházíme z myšlenky, že výkonem vlivu uvnitř skupiny mưže být dotčena i osoba věřitele. Podmínka odráží věřitelův zájem na tom, aby ovlivnění bylo učiněné $\mathrm{v}$ zákonných mantinelech s ohledem na oprávněná očekávání třetích osob. Věritel má legitimní zájem na funkčnosti vztahu mezi propojenými osobami tehdy, pokud vnější transakce ve vztahu k věřiteli existuje v úzké vazbě na vnitřní vztah mezi propojenými osobami. Mưžeme-li nalézt mezi propojenými osobami takovou intenzitu vztahů, resp. uplatněného vlivu a kontroly, který může mít dopad i do sféry třetích osob, a je-li tento zájem třetích osob uvnitř skupiny rozpoznatelný, pak je možno uvažovat o rozšíření ochranného účelu vztahu propojených osob i na osobu stojící vně skupiny (tj. věřitele skupiny).

Typicky půjde o situace, pokud závazek není plněn pouze samotným dlužníkem, ale v součinnosti s další osobou, v rámci jí uplatňovaného vlivu (např. tedy mateřská společnost). Dlužník však není pomocníkem či zmocněncem této osoby. Místo toho lze u vliv realizující osoby definovat její samostatnou zvláštní pozici jako nezávislého

122 Viz např. skutkový základ sporu dle rozsudku Nejvyššího soudu ze dne 25. 1. 2012, 29 Cdo 3661/2010; NS zde uvádí: „úcelem koncernového práva je chránit oprávnèné zájmy osob, které mohou být obroženy nebo dotčeny vžtaby mezi propojenými osobami (členy podnikatelského seskupeni - koncernu). Ačkoliv jsou členové podnikatelského seskupeni právné samostatnými subjekty, mư̌̌e vést výkon jednotného rízeni v rámi danébo seskupeni k oslabeni právníbo postaveni verritelu nebo společnikè jednotlivých členu seskupeni (obvykle ovládaných osob). $Z$ toho dìvodu i česká právní úprava ukládá členùm podnikatelských seskupeni zulástni povinnosti (srov. např. \186c obch. zák.). Právě na tyto zákonem stanovené povinnosti dopadá \ 66 b odst. 4 obch. zák., prǐčmž jazykový výklad tohoto ustanoveni vylučuje, aby do jeho vécné piisobnosti byly subsumovány i jiné povinnosti, napr. povinnosti vanikelé na základě smlouvy, jen proto, že povinnému subjektu svědči domnènka jednání ve shodě. K takovému závèru nelz̨e dospèt ani výkladem teleologickým. I když koncernové právo reflektuje ekonomické souvislosti jednáni členù koncernu, které mnohdy vykazuje silné prvky provázanosti, vycházi česká úprava zprincipu právni samostatnosti ovládajici a ovládané (rídici a ř̃zené) osoby, jenž nelze poprít výkladem navrženým dovolatelkou, který by vedl ke pričitatelnosti jednání, resp. ke vz̨niku spoludlužnického vątahu u věech povinnosti osob jednajicich ve shodě s jïním subjektem, ze všech smluv, keteré některá z nich uzavrela. " 
jednajícího, spolupůsobícího na plnění závazku, vykonávajícího práva vlivu či instrukcí nad plněním, které poskytuje však sám dlužník (ovlivněný).

Právě v těchto př́padech je dále možné zvažovat podmínky, které umožňují aplikaci institutu culpa in contrahendo vưči třetím osobám, o kterých bylo pojednáno výše. Pro dovození ochranných povinností na straně osoby vykonávající vliv můžeme nalézat tyto typové situace:

a) Existence zvláštního vztahu důvěry: ten může být dán např. tím, že transakce s věritelem je učiněna pod jednotící „značkou“ skupiny, kdy se mateřská společnost vlastním jednáním aktivně spolupodílí na vybudování oprávněných očekávání na straně věritele, která následně nejsou naplněna. Tyto úvahy vychází z myšlenky, že by měla být uznána kritéria, která brání skupině společností „těžit“ z výhod jednotného vzezrenení, ale $\mathrm{v}$ př́padě odpovědnosti se dovolávat formálního oddělení jednotlivých společností. Ekonomická výhoda, která je realizována získáním zvláštní důvěry $\mathrm{v}$ jednotu skupiny, musí být doplněna odpovídající ochranou důvěry věřitele. ${ }^{123}$ Jak bylo již uvedeno, prrípadem, který není pokryt prímo touto podmínkou, ale je jí na roveň postaven, je situace:

b) Intervence do závazku: vlivná osoba (mateřská společnost) nevyužije sice zvláštní důvěry v ní vkládané, ale její zájem na výsledku je natolik eminentní, že ovlivňuje chování dlužníka. Mateřská společnost musí mít vliv na formování závazku, jeho trvání (např. v možnosti a zpưsobu plněnî) či jeho porušení. Př́klady takového vztahu lze ilustrovat např. vlastnictvím obchodního modelu, kontrolou nad klientskými smlouvami, kontrolou nad servisním a technickým aparátem apod. Konkrétní zásah do závazku může být projevem skutečnosti, že vlivná osoba má na závazku:

c) Vlastní silný ekonomický zájem: existence tohoto vlastního ekonomického zájmu vliv realizující osoby na plnění závazku musí být vykládána restriktivně. Nelze tím vidět jen napřr. možnost provize či (v kontextu kapitálově propojených osob) podílu na zisku. ${ }^{124} \mathrm{~V}$ zásadě budou tyto podmínky splněny, pokud společnost v rámci skupiny jedná jako „prodloužená ruka“ a v rámci závazku realizuje činnost, která se úzce dotýká vlastní podnikatelské činnosti mateřské společnosti.

Společným jmenovatelem těchto variant je jistá míra kontroly, kterou mateřská společnost prostřednictvím jedné ze smluvních stran vykonává a jež se projeví v porušení závazku. Existence kontroly může být založena na právních či faktických okolnostech, avšak sama o sobě není adekvátním základem pro založení odpovědnosti mateřské společnosti, a to ani tehdy, pokud je tato kontrola věriteli známa. ${ }^{125}$ Rozhodující pro založení odpovědnosti je aktivní výkon této kontroly, který může spočívat v okolnostech shora

123 BROICHMANN, A. a J. BURMEISTER. Konzernvertrauenshaftung - zahnloser Tiger oder tragfähiges Haftungskonzept? In: Neue Zeitschrift für Gesellschaftsrecht, 2006, č. 18, s. 690.

124 RIECKERS, O. Nochmals: Konzernvertrauenshaftung. In: Neue Zeitschrift für Gesellschaftsrecht, 2007, č. 4, s. 126.

125 SPINDLER, G. Unternehmensorganisationspflichten: zivilrechtliche und öffentlich-rechtliche Regelungskonzepte. 2., nezměněné vyd. Universitätsverlag Göttingen, 2011, s. 971. 
popsaných, tedy jakýsi pomyslný „plus faktor“"126 ve vztahu vzájemně propojených osob, který má dopad do sféry věřitele.

Za těchto podmínek je možno konstruovat existenci ochranných (vedlejších, pomocných) povinností, které nezavazují pouze smluvní strany, ale jejichž porušení se může strana závazku dovolávat prrímo i vůči „,vnějšsí“ osobě vykonávající vliv na transakci. Odpovědnost tak není navázaná, jako v případě ovlivnění dle $\int 71$ ZOK, na korporátní vztah mezi propojenými osobami, nýbrž vychází z vlastního vztahu mezi osobou vykonávající vliv na korporaci a jejími věřiteli. ${ }^{127}$

Přičítání odpovědnosti mateřské společnosti nemůže být založeno pouze na základě porušení závazku s klientem a na základě vztahu mezi osobami. Je nutné zkoumat konektivitu (spojitost) ${ }^{128}$ mezi vztahem uvnitř skupiny a důvodem porušení závazku. Odpovědnost osoby vykonávající vliv nezahrnuje všechny př́ipady odpovědnosti za porušení závazku, které mohou nastat. Naopak, je omezena na vlastní porušení povinnosti ve vazbě na jejím podílu na celkovém plnění ve prospěch konečného klienta. V zásadě je tak odpovědnost redukována na systémové chyby (chyby v rámci technického obchodního konceptu, know-how, vývoji, vzdělávání pracovníků či kontrole), ${ }^{129}$ či na přímou (úmyslnou) intervenci do závazku mezi smluvními stranami, která věřiteli způsobí škodu.

\subsection{Culpa in dominando adversus tertium}

Podobnou koncepci ve své práci představuje i F. Temming, ${ }^{130}$ který rozpracovává ochranu věřitele $\mathrm{v}$ prrípadech, kdy je závazek dotčen kontrolou či dominancí třetí strany (der vertragsbeherrschende Dritte). ${ }^{131}$ Dovozuje, že vliv třetí osoby na závazek zakládá zvláštní mimosmluvní vztah mezi kontrolující stranou a věřitelem na základě aplikace $\int 311$ odst. 2 a 3 BGB. Pokud pravidlo culpa in contrahendo umožňuje založit odpovědnostní závazek třetí osoby v prrípadě, kdy je třetí osobou zástupce (Sachwalter) či osoba jednající procurator in rem suam, pak obdobně (argumentum a minore ad maius) musí být toto pravidlo aplikováno na osoby, jejichž vliv na „cizí“ závazek má podstatně významnější intenzitu.

126 FLEISCHER, H. Konzernvertrauenshaftung und corporate advertising - ein aktueller Streifzug durch die schweizerische Spruchpraxis zum Konzernaußenrecht. In: Neue Zeitschrift für Gesellschaftsrecht, 1999 , č. 15 , s. 692.

127 BROICHMANN, A. a J. BURMEISTER. Konzernvertrauenshaftung - zahnloser Tiger oder tragfähiges Haftungskonzept? In: Neue Zeitschrift für Gesellschaftsrecht, 2006, č. 18, s. 689.

128 Jakkoliv patrně nejde o nejvhodněji zvolený český termín, ve své práci s tímto termínem pracuje i TEUBNER, G. Networks as Connected Contracts. Portland: Hart Publishing, 2011, s. 263.

129 TEUBNER, G. Networks as Connected Contracts. Portland: Hart Publishing, 2011, s. 263.

130 TEMMING, F. Der vertragsbeherrschende Dritte: Drittbeherrschte Schuldverbältnisse und Sonderverbindungen i.S.d. $\int 311$ Abs. 3, 2 Nr. 3 BGB unter besonderer Berücksichtigung des Konzernhaftungsrechts. Nomos, 2015, s. 1001-1104.

131 Jisté problémy přináší již český překlad tohoto termínu, patrně nejlépe by bylo možno hovořit o „,smluvněovládajících třetích osobách“. 
Tato východiska vedou F. Temminga ke konstrukci institutu culpa in dominando adversus tertium. Byla-li základním východiskem v založení odpovědnosti dle culpa in contrahendo existence zvláštního vztahu důvěry (a jeho derivátů, které jsou shora blíže rozebrány), je culpa in dominando založena na základě existujícího vlivu a možnosti zasáhnout od práv a oprávněných zájmů třetích osob. ${ }^{132}$

Předpokladem této odpovědnosti je existence kontroly (dominance) třetí osoby nad závazkovým právním vztahem mezi dvěma jinými subjekty. Tato kontrola nastává, pokud třetí strana může vykonávat vliv na jednu ze smluvních stran, at’ již je důvod založen na právních či faktických okolnostech výkonu vlivu prostřednictvím instrukcí či řízení. Objektivní odpovědnost kontrolující osoba přebírá zejména tehdy, pokud nese korporátní anebo insolvenční riziko smluvní strany, kterou ovládá. Dominanci odpovídá závislost jedné ze smluvních stran na třetí osobě v př́padě, jestliže je vázána jejími pokyny či faktickým vlivem. ${ }^{133}$ Citovaný autor tyto myšlenky rozvíjí zejména v kontextu ochrany pracovněprávního poměru, přesto jeho úvaha je obecnější a pojímá především př́pady, kdy jde o smlouvy s dlouhodobým, opakujícím se plněním, jež jsou krom právní regulace založeny též na dalších sociálních vazbách mezi stranami. ${ }^{134}$

Autor však svoji úvahu ještě dále prohlubuje a dovozuje, že vzhledem k vazbě na již existující závazek, lze na straně osoby vykonávající kontrolu konstruovat i pozitivní povinnost směřující k naplnění závazku, jehož není smluvní stranou (obligatio in dominando adversus tertium); v těchto případech se strana závazku mưže po třetí osobě domáhat nejen náhrady škody v penězích, ale s odkazem na \249 BGB (obdobně \2951 odst. 1 OZ) i naturální restituce, tedy splnění samotné povinnosti z jejího závazkového právního vztahu. ${ }^{135}$

\subsection{Limity ochranných schémat a jejich aplikace na modelové př́íklady}

Je patrné, že obě shora popsané myšlenkové linie jsou si velmi podobné. Obě však naráží na podobné limity spočívající v konkrétní definici podmínek jejich užití. V otázce osobní působnosti této doktríny Temming vychází ze statusu kontrolující osoby (der vertragsbeherrschende Dritte); v našich úvahách, a to i vzhledem k absenci kodifikovaného pravidla, které by obsahově odpovídalo \311 odst. 2 a 3 BGB, vycházíme z podobnosti podmínek aplikace smluv s ochranným účinkem vưči třetí osobě, tak jak jsou pojímány v kontextu

132 TEMMING, F. Anerkennung und Grenzen eines konzerndimensionalen Kündigungsschutzes. In: Recht der Arbeit, 2018, č. 2, s. 95 a násl.

133 Ibid.

134 Hovoří se o tzv. ,,relational contracts“, vytvářejích dlouhodobý sociální vztah mezi stranami. MACNEIL, I. Relational Contract: What we do and do not know. Wisconsin Law Review, 1985, č. 3, s. 483-525.

Z české literatury jisté prvky tohoto jevu zmiňuje NOVÝ, Z. Dobrá víra jako princip smluvního práva v mez̧inárodním obchodu. Praha: C. H. Beck, 2012, s. 10 a násl.

135 TEMMING, F. Anerkennung und Grenzen eines konzerndimensionalen Kündigungsschutzes. In: Recht der Arbeit, 2018, č. 2, s. 96. 
\2913 OZ. Kritéria, za kterých lze tuto reflexi použít jsou však rámcově užší (konzervativnějšî), nebot' v námi nastíněné úvaze nepostačí k dovození odpovědnosti toliko vztah kontroly, ale podstatné je jeho promítnutí do sféry chráněného závazku. Myslím však, že v praktické rovině jsou si obě myšlenkové roviny relativně blízké, byt' námi zkoumaná proximita ve své podstatě představuje kontrolu (vazbu) zkoumanou v kontextu jednotlivého prŕpadu, naopak prvek kontroly formulovaný Temmingem je pojímán obecnēji. V obou př́padech půjde o typové situace, kdy třetí osoba má „moc“ nad smluvní pozicí jedné ze stran. Jakkoliv vytyčení mantinelů tohoto předpokladu bude nanejvýš kazuistické, obecně si lze představit vysoce integrovanou skupinu společností, která fakticky realizuje svoji činnost prostřednictvím úzce propojených samostatných společností. Za této konstelace oba př́stupy vedou k obdobnému závěru.

Větší obtíže po mém soudu přináší otázka, jakých konkrétních povinností se lze pak vưči osobě vykonávající vliv dovolávat. I pokud vyjdeme z premisy, že vưči třetí osobě vznikají toliko ochranné, pomocné povinnosti, vymezení obsahu ochranných povinností není nijak ostré. ${ }^{136}$ Omezená specifikace ochranných povinností je předurčena tím, do jaké míry jsou postaveny na relativně otevřených právních konceptech, normách s neurčitou právní hypotézou, nebot' nejde o nic jiného než o konkretizovaný projev principu poctivosti. V kontextu rozebírané culpa in contrahendo J. Hrádek upozorňuje, že ,konkrétní rozsah povinnosti ochrany už předmětem odlišného chápání být může, nebot' se na něm projevují zásady vlastní každému právnímu řádu, jako je dobrá víra, dobré mravy či poctivý obchodní styk “. ${ }^{137}$ Jednotlivé skutkové podstaty se i v německém právním prostředí neustále vyvíjí. V poslední době je kladen důraz na vzájemnou loajalitu, ochranu vložených investic, ochranu slabší strany či respekt k zájmům ostatních. ${ }^{138}$ V kontextu probíraného tématu je klíčová zejména informační povinnost vưči věřiteli. ${ }^{139}$ Podstatu takovýchto ochranných a prevenčních povinností však patrně nejlépe vystihuje J. Šilhán, který poukazuje na jejich zvláštní kvalitu, nebot’ jsou „,mnohem konkrétněji naplněny individuálním obsahem. Jejich konkrétní kontury se v jednotlivých situacích neodvíjí jen od obecně uplatňovaných objektivizovaných standardů, ale jsou precizovány, resp. ze své poněkud abstraktní podoby transformovány do podoby velmi

136 Obecně bývá uváděna např.: a) povinnost nepůsobit škodu, b) povinnost brát ohled na cizí zájmy a obecná informační povinnost, c) zákaz ukončení vyjednávání o smlouvě. HRÁDEK, J. Předsmluvní odpovédnost: Culpa in contrahendo. Praha: Auditorium, 2009, s. 47; dále d) povinnost kooperace či součinnosti, e) dobrověrného plnění smlouvy, f) povinnost diskrétnosti, g) informační povinnosti, h) povinnost opatrovat svěrené věci. ŠILHÁN, J. Právni následky porušeni smlouvy v novém občanském zákoníku. Praha: C. H. Beck, 2015, s. 40.

137 HRÁDEK, J. Předsmluvní odpovědnost. In: Bulletin advokacie, 2011, č. 3. s. 45.

138 KRÜGER, W. et al. Münchener Kommentar zum Bürgelichen Gesetz̧buch. Band 2a. Schuldrecht Allgemeiner Teil. 4. Teil. München: C.H. Beck, 2003, s. 1493-1494, cit. dle MATULA, Z. Culpa in contrahendo. Praha: Wolters Kluwer, 2012, s. 111.

139 RIECKERS, O. Nochmals: Konzernvertrauenshaftung. In: Neue Zeitschrift für Gesellschaftsrecht, 2007, č. 4, s. 126. 
konkrétní, odpovídající daným závazkovým okolnostem. “140 Tyto okolnosti daného př́ipadu (jež jsou vyjádřeny i v prevenční klauzuli \2900 OZ) mohou zrcadlit i výkon vlivu třetí osoby na závazkový právní vztah a mohou tak odrážet specifika existence kontroly mezi propojenými osobami ve sféře věřitele jedné z nich. Konkrétní specifikace limitů pak zůstává úlohou rozhodovací praxe a další doktríny.

$\mathrm{S}$ vědomím tohoto omezení nezbývá než se vrátit k příkladům shora uvedeným a pokusit se rekonstruovat výše uvedené závěry na půdorysu popsaných skutkových okolností. První popisovaný prípad (příklad „Fiat“) umožňuje ilustrovat situaci, kdy lze uvažovat o založení povinnosti k náhradě škody u osoby vykonávající vliv na závazek. Popsaný př́pad vzájemně propojených smluv mezi distribučním střediskem Fiat a úrovní dealera A na jedné straně a mezi distributory na straně druhé nás vede k závěru, že podmínka proximity zde byla naplněna, nebot' externí smlouvy byly uzavírány v úzké souvislosti a podřízenosti vztahu $\mathrm{k}$ distribučnímu centru Fiat. V tomto př́padě je podmínka „dopadu do sféry třetí osoby“, na kterém stojí kritéria smlouvy s ochranným účinkem vưči třetím osobám, naplněna, protože vztah je založen na výkonu kontroly, která se zrcadlí ve zjištění, že realizace transakce v rámci distribuce je dokončena ve prospěch klienta až na další úrovni. Dále je nutné zkoumat povahu interního vztahu na úrovni distributor A - distributor B v tom smyslu, zda odůvodňují vznik ochranných povinností na straně třetí osoby, tedy distribučního centra Fiat. Zde je podstatné zjištění, že tato smlouva se odvijela od smluv s distribučním centrem, kdy podmínky plnění závazku z této smlouvy byly predeterminovány činností na úrovni centra. U věřitele lze předpokládat rozumné očekávání, že dílčí úkony v rámci plnění závazku jsou koordinovány na centrální úrovni, tedy smluvně definovaným kooperačním vztahem mezi jeho smluvní stranou a distribučním centrem. Pokud pak došlo k porušení závazku - v popisovaném př́padě šlo o protiprávní výpověd’ smlouvy - které bylo iniciováno ze strany osoby mající vliv na druhou smluvní stranu, je takové jednání porušením ochranných povinností a povinnost k náhradě škody může být založena i vưči distribučnímu centru Fiat.

Druhý popsaný případ (př́klad „WV“) se výrazně liší. Ani při aplikaci shora popisných schémat totiž nelze dovodit protiprávnost ani na straně leasingového pronajímatele, ani na straně prodejce automobilů. Jak soud správně uvážil, tento závazek byl nezávislý na vztazích ke skupině WV. Zajímavější úvahy však přináší lehce pozměněný scénár̆, pokud by výpověd' smlouvy směřovala přímo vưči dceřiné společnosti proto, že na úrovni mateřské společnosti došlo k manipulacím s výsledky emisních limitů. Bylo nastíněno, že narušení vzájemné důvěry může u dlouhodobých vztahů založit protiprávnost, která může být důvodem pro výpověd' závazku. Formálně vzato však tento důvod nemůže dopadat na dceřinou společnost, pokud jí nelze toto jednání přičítat. Mám však za to, že rozšíření ochranného účelu smlouvy by tuto úvahu odůvodňovalo za předpokladu,

140 ŠILHÁN, J. Právni následky porušeni smlouvy v novém občanském qákoníku. Praha: C. H. Beck, 2015, s. 35. 
že okolnost, jež vedla k narušení vztahu důvěry u mateřské společnosti, se může projevit i v závazku mezi dceřinou společností a věřitelem. Tak by tomu bylo např́iklad tehdy, jde-li o věcně propojené produkty, jež nabízí mateřská a dceřiná společnosti. Z toho plyne další dílčí závěr, jež celé aplikační schéma rozšiřuje: pakliže celá konstrukce stojí na dovození ochranných povinností i vưči mateřské společnosti, pak zásah do těchto povinností mưže vyvolávat i další následky spojené s porušením smlouvy než pouze povinnost náhrady škody z tohoto zásahu vzešlé (např. právo odstoupit od smlouvy).

Nutno upozornit, že tyto modelové situace byly záměrně zvoleny jako hraniční, a jistě je snadné představit si př́ípady, které navrhované schéma ochrany kopírují intuitivněji. ${ }^{141}$ Také je patrné, že toto schéma přesahuje kontext konzervativně vnímané skupiny společností a může dopadat i na situace, kdy je výkon vlivu odrazem specifického závazku mezi stranami.

\section{Závěrem - dílčí shrnutí a vztah k ovlivnění}

Potřeba zvláštních odpovědnostních režimů ochrany věřitele korporace začleněné do podnikatelského seskupení prestavuje jednu z největších výzev moderního korporátního práva. ${ }^{142}$ Bylo již uvedeno, že i domácí právní věda nezřídka odkazuje na závěry zahraničních doktrín spojených s prolamováním korporátního závoje (Piercing the Corporate Veil). V těchto př́padech je nástrojem ochrany věřitele př́konání majetkové samostatnosti právnické osoby. $\mathrm{V}$ této stati byly nabídnuty takové prostředky ochrany věritele, které mohou sloužit témuž účelu, avšak aniž by byla majetková samostatnost právnické osoby zapojené do skupiny společností zpochybňována. V zájmu ochrany věritele v těchto př́padech je na místo toho „prolamována“ relativita závazkového právního vztahu, nebot' jsou nacházeny nástroje, které reflektují výkon kontroly nad smluvní pozicí formálně samostatné korporace. Zpochybnění relativity závazku za účelem ochrany věřitele je (stejně jako v př́padě prolamování majetkové samostatnosti) nutno chápat jako výjimku z pravidla, ultima ratio, která má toliko reagovat na nepřiměřený přenos externalit, jež mohou stíhat věřitele podnikatelského seskupení.

Pro přehlednost lze závěrem připojit krátké shrnutí aplikačních podmínek dovozovaného schématu ochrany věřitele. Shora dovozený koncept odpovědnosti vlivné osoby vưči věriteli osoby ovlivněné předpokládá:

1. Existenci proximity, tzn. že věřitel má legitimní zájem ve „funkčnost“ vztahu mezi propojenými osobami, resp. že může být dotčen kvalitou tohoto vztahu. Podmínka odráží intenzitu vztahu mezi propojenými osobami.

141 Srov. zejména př́klad uvedený v pozn. č. 36.

142 ANKER-SØRENSEN, L. Parental Liability for Externalities of Subsidiaries: Domestic and Extraterritorial Approaches. Nordic \& European Company Law Working Paper [online]. 2014, č. 14-06, s. 102-118, s. 104 [cit. 14. 6. 2019]. Dostupné z: http://dx.doi.org/10.2139/ssrn.2506508 
2. Rozšíření ochranného účelu závazku - důvod pro jeho rozšíření bude zejména tehdy, pokud výkon kontroly učiněný vlivnou osobou na smluvní stranu mưže mít dopad do sféry chráněného závazku. Konkrétní projevy této podmínky nastávají tehdy, pokud lze u vlivné osoby nalézt prvky (i) požívání zvláštní důvěry ve vztahu k věriteli nebo (ii) aktivní intervence této osoby do formování obsahu závazku či do jeho trvání, či (iii) zvláštní ekonomický zájem na uzavření či plnění smlouvy.

3. Konektivita, spojitost - přičítání odpovědnosti nemůže být založeno pouze na základě porušení závazku mezi korporací a věřitelem a na základě kvalifikovaného vztahu mezi propojenými osobami. Odpovědnost vlivné osoby je omezena na vlastní protiprávní jednání, vznikající pravidelně ve vazbě na účast vlivné osoby na formování obsahu a trvání závazku mezi věřitelem a osobou podřízenou

Bylo by snad možné namítat, zda je taková koncepce nutná a potřebná a zda nevystačíme s běžnými nástroji ochrany věritele korporace, jejíž jednání je ovlivněno třetí osobou, zejména s ohledem na ochranu poskytovanou $\int 71$ ZOK. Na samotný závěr je proto nutné uvést krátkou „obranu“ předchozích řádků ve vazbě na možný překryv popsaného odpovědnostního schématu s institutem ovlivnění (tak jak je pojímán \ 71 ZOK). Jak již bylo uvedeno, ve zde uvažovaných případech jde o ochranu před jinou kvalitou zásahu, než jakou předpokládá \ 71 ZOK. Posledně řečené chrání věřitele před takovým jednáním mateřské společnosti, kdy je výkonem vlivu ohrožena existence jeho dlužníka, resp. jeho schopnost plnit. Zde popsané schéma pokrývá prŕklady, kdy může dojít k realizaci vlivu uvnitř skupiny, které se negativně promítne do sféry věřitele, a neschopnost plnit na straně dlužníka může být založena i z jiných důvodů, než je samotný výkon vlivu. S uvedeným souvisí zejména podmínka $\int 71$ odst. 3 ZOK, kdy je ručení vlivné osoby předpokládáno pouze $\mathrm{v}$ případech, kdy je neschopnost plnění dlužníka založena právě $\mathrm{v}$ důsledku ovlivnění. $\mathrm{V}$ tomto směru se ochranná sféra věřitele oproti ovlivnění rozšriruje.

Obdobně, $\mathrm{k}$ rozšíření ochrany věřitele dochází v tom smyslu, že újmy vưči věřiteli se vlivná osoba nemůže zprostit poukazem na liberační důvody předpokládané v \ 71 odst. 1 ZOK. ${ }^{143}$ Základní rozdíl je dán ve skutečnosti, že ve zde rozebíraném schématu odpovědnosti odpovídá vlivná osoba přímo věřiteli za vlastní protiprávní jednání; jde o odpovědnost vnější, externí - oproti vnitřní konstrukci ovlivnění, která je založena na interní odpovědnosti s ručením za dluhy.

Je však evidentní, že může docházet k překryvům, kdy konkrétní situace mohou zakládat jak odpovědnost dle výše popsaných pravidel, tak dle pravidel ovlivnění $\int 71$ ZOK.

$143 \mathrm{Na}$ tomto místě ponechme stranou, zda je odpovědnost dle $\int 71 \mathrm{ZOK}$ nutno nahlížet jako odpovědnost subjektivní pro porušení ochranné normy (HAVEL, B. In: ŠTENGLOVÁ, Ivana, Bohumil HAVEL, Filip CILEČEK, Petr KUHN a Petr ŠUK. Zákon o obchodních korporacích. Komentár. 2. vyd. Praha: C. H. Beck, 2017, 1144 s., s. 199-208, mrg. 8. ISBN 978-80-7400-540-4), nebo odpovědnost objektivní (PELIKÁNOVÁ, I. Obchodní právo. 5, Odpovédnost s priblédnutím ke návrbu novébo občanského zákoníku. 1. vyd. Praha: Wolters Kluwer Česká republika, 2012, 356 s.). 
Pro to hovoři srovnatelná konstelace ekonomických zájmů zúčastněných osob v obou př́padech. Toto tvrzení závisí zejména na specifikaci konkrétních podmínek, které vymezují vlivnou (zde ve smyslu $\int 71 \mathrm{ZOK}$ ) osobu a její povinnost hradit škodu. Ty jsou doposud předmětem diskusí, zejména jde-li o jinou osobu než dominantního společníka, např. věritele. ${ }^{144} \mathrm{~V}$ tomto ohledu se domnívám, že i pokud by navržené odpovědnostní schéma vlivné osoby založené na její vlastní protiprávnosti bylo shledáno nepotřebným ve vztahu k ovlivnění, je jeho význam přinejmenším interpretační, nebot' nám umožňuje proniknout hlouběji do vzájemných vazeb propojených osob v relaci ochrany věřitele. Shora popsané podmínky tak mohou být návodnou pomůckou, jež odhaluje př́pady, kdy lze uvažovat o dobrých důvodech založení odpovědnosti vlivné osoby, nebot' její vliv na korporaci zasahuje do sféry věřitele. To může být významné zejména $\mathrm{v}$ úvahách o věriteli jako vlivné osobě ve smyslu \ 71 ZOK. Tento závěr logicky odráží konkrétní projevy téhož principu poctivosti v obou př́padech (\$ $6 \mathrm{OZ})$, povinnosti jednat s náležitými znalostmi a péčí (\ 4 a $5 \mathrm{OZ}$ ) a povinnost nepůsobit jinému bezdůvodně újmu, jež se zrcadlí v obecných ochranných a prevenčních normách (\2900 a \2901 OZ).

$144 \mathrm{~K}$ tomu např. HAVEL, B. Věritel coby vlivná osoba (aneb vliv není totéž co být pod vlivem). In: XXIV. Karlovarské právnické dny. Praha: Leges, 2016, 540 s.; HAVEL, B. O kogentnosti, vypořádání újmy a ručení vlivné osoby ve světle nového soukromého práva. In: Obchodnéprávní revue, 2013, č. 1, s. 13 a násl.; HAVEL, B. In: ŠTENGLOVÁ, Ivana, Bohumil HAVEL, Filip CILEČEK, Petr KUHN a Petr ŠUK. Zákon o obchodních korporacich. Komentár. 2. vyd. Praha: C. H. Beck, 2017, 1144 s., s. 199-208, mrg. 8. ISBN 978-80-7400-540-4; ČERNÁ, S. Ještě k ručení vlivné a ovládající osoby za porušení povinnosti odvracet hrozící úpadek. In: Obchodněprávni revue, 2013, č. 6, s. 169 a násl.; ČERNÁ, S. O koncernu, koncernovém řízení a vyrovnání újmy. In: Obchodněprávní revue, 2014, č. 2, s. 33 a násl.; ČERNÁ, S. Ovlivnění jako klíčový pojem českého koncernového práva. In: Rekodifikace a praxe, 2014, č. 1, s. 14 a násl. 